\title{
وجهة الضبط وعلاقته بالغضب \\ لدى المراهقين المتعاطين لأدوية السعال
}

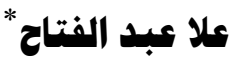

تلتاول الورقة الراهنة متغير الغضب وعلاقته بوجهة الضبط لدى عينة من المراهقين المتعاطين

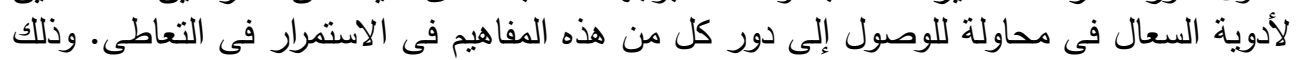

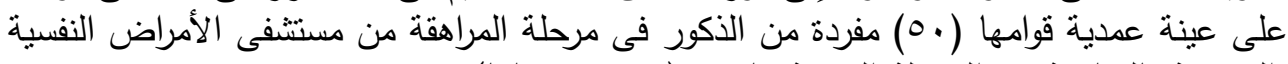

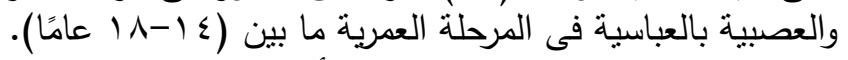

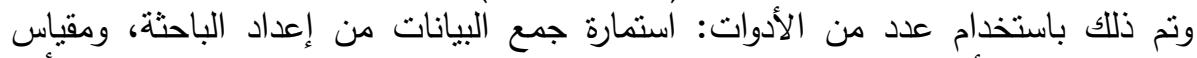

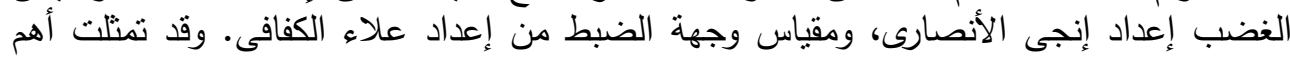

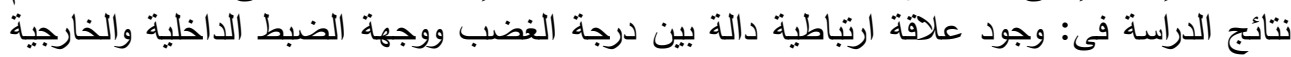

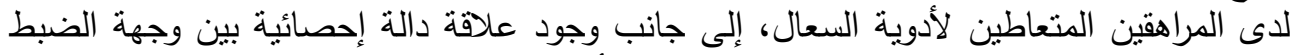

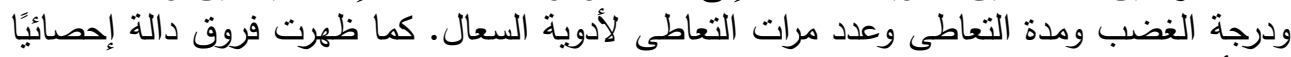

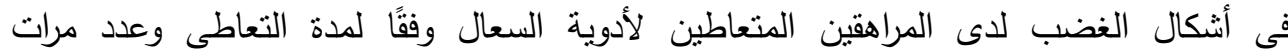

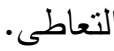

\section{مقدهة}

يعد الإدمـان مـن المشكلات التى تلقى اهتمائًا كبيـرًا مـن جميـع المؤسسـات، وقد تعـددت الجهـود فـى هــا الثــأن وتعددت البحوث والدراسـات بسبب زيادة معدل تعاطى المخـدرات بمختلف صسورها، وقد تلاحظ مؤخرًا انتشـار مـا بسـى بالإدمـان

$$
\text { الثرعى. }
$$

وقد أضيفت الثرعية إلى هذا النوع من الإدمان لأن القانون لا يعاقب عليه، ويقـر شرعيتهـ باعتبار أن المادة التى يتم تعاطيها تقع تحت مسمى الدواء، وهنا يتم * مدرس، الأكاديمية الحديثة بالمعادى.

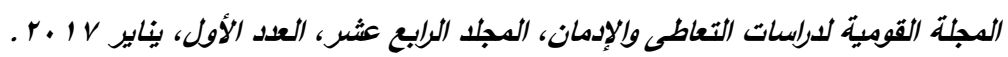


التعاطى على أساس هذه الثقافة التبريرية لتعاطى بعض الأدوية والابتعاد الكامل عن

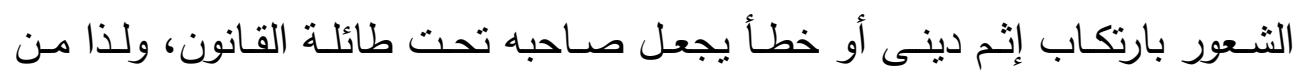

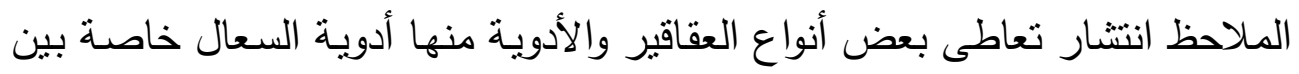

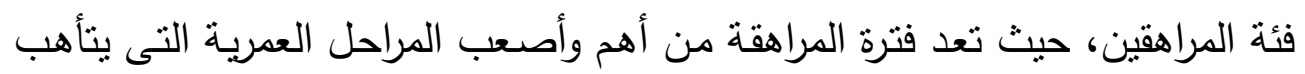

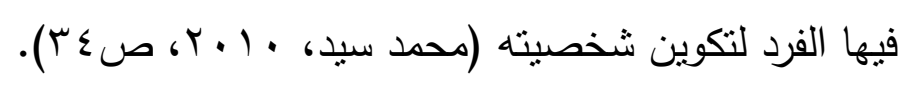

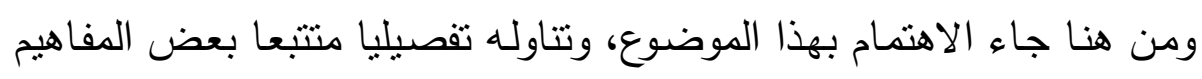
التى قد تكون لها علاقة فعلية بتعاطى أدوية السعال خاصة، وقد كانت هناك الك جهود

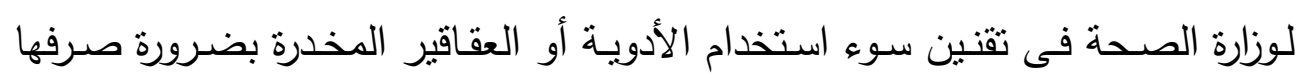
بأمر من الطبيب.

ومن هذا المنطلق نتـاول فى الورقة الراهنـة متغير الغضب وعلاقته بوجهة

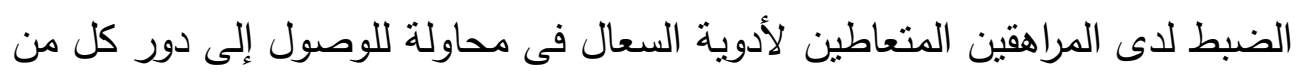

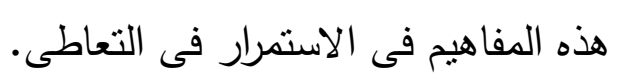

\section{أولاً: تحديد المشكلة}

على الرغم من الجهود المبذولة فى مجال الوقاية والعلاج من تعاطى المخدرات بصفة

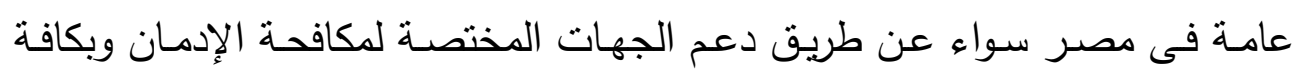

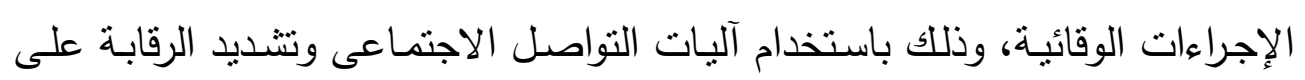

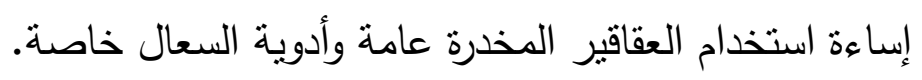

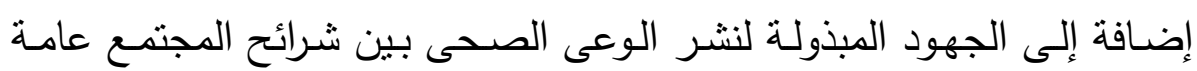

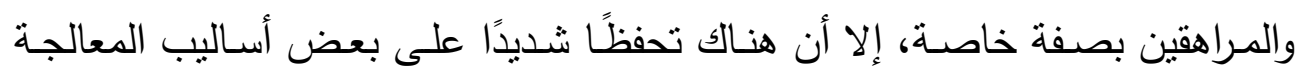

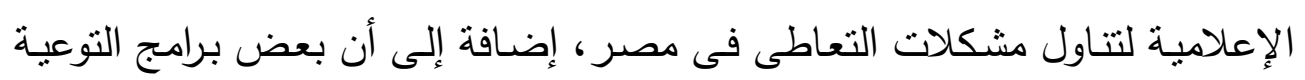
المقدمة لا تتم وفقًا لمنهجية علمية مدروسة لذلك لم تحقق النتيجة المطلوبة. 
ومن هنا جاءت ضرورة الوقوف على دراسـة بعض المفاهيم التىى لم تتتاولها

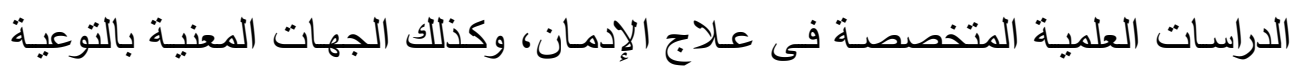

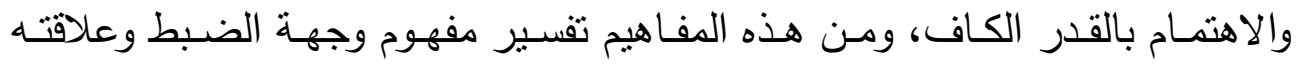
بالغضـب لـدى المـراهقين المتعـاطين لأدويـة السـعال وهـو متعــارف عليـهـ بالإدمـان

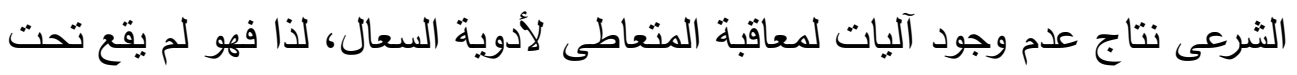

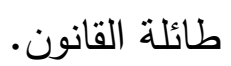

وقد تغلغل هذا النوع من الإدمان وأصبح متداولًا بين جماعات المراهقين على العى

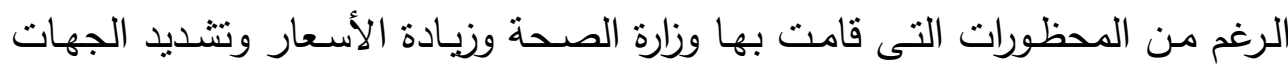

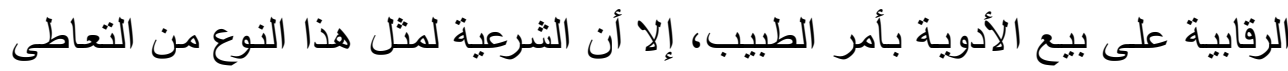

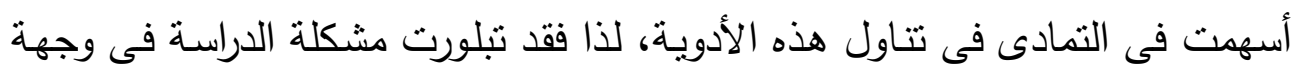
الضبط وعلاقتها بالغضب لدى المراهقين المتعاطين لأدوية السعال.

\section{ثانيا: أهمية الدراسة}

تعد مشكلة إساءة استخدام أدوية السعال خاصة لدى فئة المراهقين فى مصر من أهم المشكلات المؤدية لتفاقم مشكلة الإدمان، وعلى صعيد آخر فإن الجهود المبذولة من الندانه

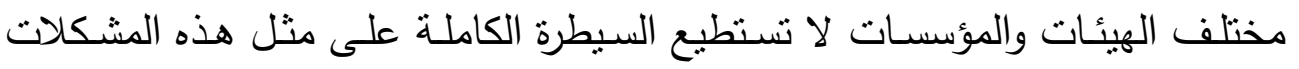
لاتساعها وعدم وجود إطـار محدد لها؛ حيث إن تجاوز مشكلة تعاطى المراهقين

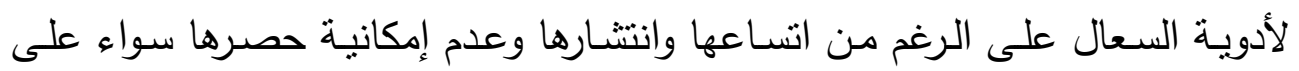

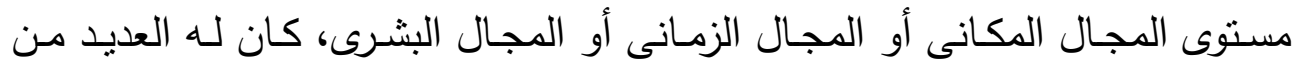

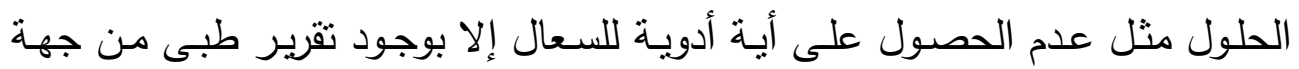

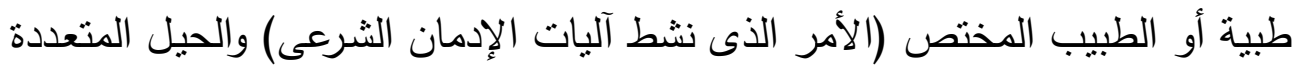

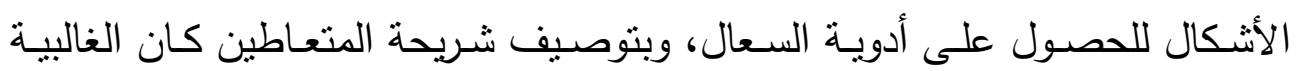




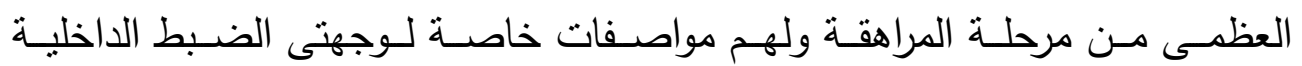
والخارجية، وأيضًا أنماط وأنشكال للغضب منس منعددة.

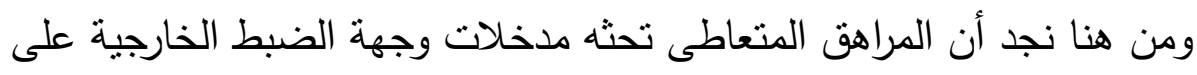

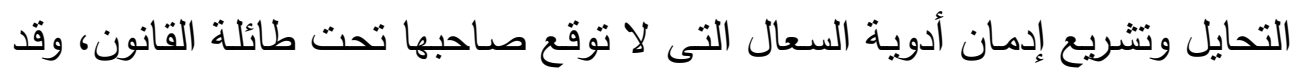

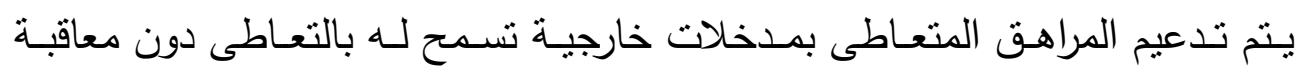

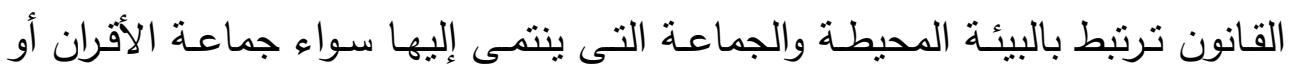
الجماعة المدرسية.

وتعد هذه الدراسـة من الدراسـات التى من شـأنها إضـافة أهميـة كبرى لمعرفـة

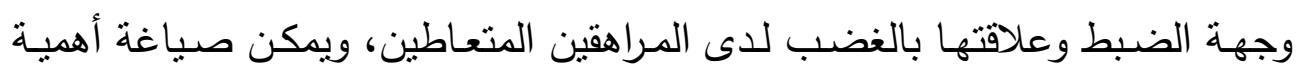

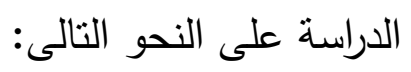

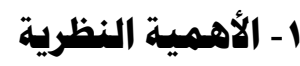
• إثراء البنـاء المعرفى بالعديد مـن المفـاهيم النفسية والاجتماعيـة المتعلقـة بـنمط

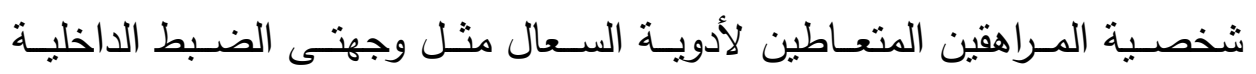
والخارجية وعلاقته بالغضب. • ل التعرف على العوامل المؤدية إلى تعاطى أدوية السعال.

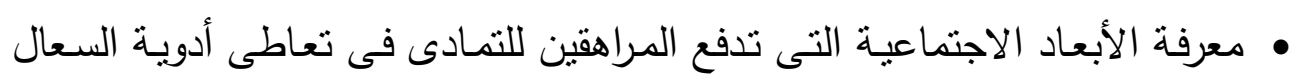
المسموح بها طبيًا طالما لا يعاقب عليها القانون.

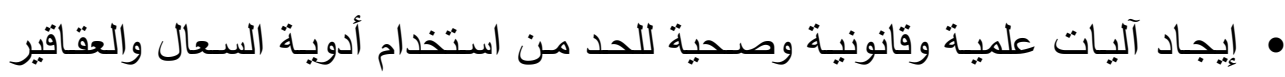
المخدرة المسموح بها طبيًا. 
• إيجـاد بـرامج تطبيقيـة لتوعيـة المـراهقين بمحددات استخدام أدويـة السـعال خاصـة والعقاقير المخدرة عامة فى مراكز الثباب.

• إيجاد إجراءات ميدانية لاحتواء ظاهرة أدوية السعال المسموح بها طبيًا وحصرها والقضاء عليها.

• إيجـاد بـرامج فعليـة وتوعويـة للأسـرة والمؤسسـات الصـحية والمعنيـة بتداول أدويـة السعال. • تفعيل الدور الرقابى للمؤسسات المتخصصة المعنية بالحد من الإدمان. • تفعيل دور المجالس المتخصصـة لمكافحة الإدمـان برسم سياسـات تكون الركيزة الأساسية فيها التشخيص الميدانى لظاهرة التعاطى.

\section{ثالثا: أهد|ف الدراسة}

تتمثل أهداف الدراسة الراهنة فيما يلى: • التعرف على أبعاد وأنماط ظاهرة تعاطى أدوية السعال لدى المراهقين. • التعرف على العلاقة بين الغضب ووجهة الضبط لدى المراهقين المتعاطين لأدوية السعال وفقًا لمدة التعاطى. • التعرف على نوع العلاقة بين الغضب ووجهة الضبط لدى المراهقين المتعاطين

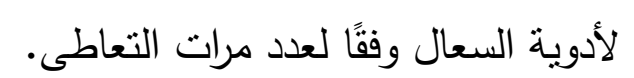
• التعرف على العلاقة بين أشكال الغضب ومدة التعاطى لدى المراهقين المتعاطين لأدوية السعال. • التعرف على العلاقة بين وجهة الضبط لدى المراهقين المتعاطين لأدوبة السعال ومدة التعاطى. 
• التعرف على العلاقة بين أثكال الغضب وعدد مرات التعاطى لأدوية السعال لدى المراهقين. • التعرف على العلاقة بين وجهة الضبط وعدد مرات التعاطى لأدوية السعال لدى المراهقين.

\section{رابعاً: تساؤلات الدراسة}

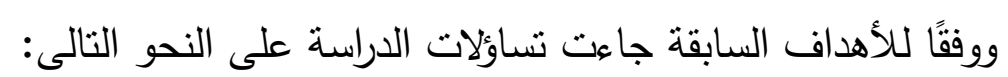

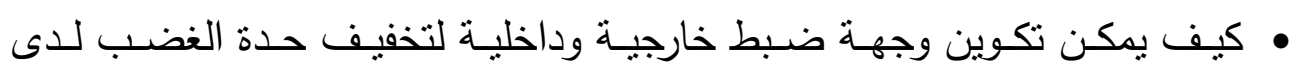

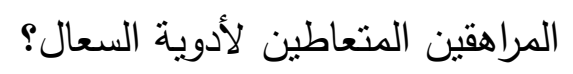

• مـا أشكال الغضب لدى المـراهقين التى تجعلهم يتحكمون في نزعاتهم الداخلية لادية

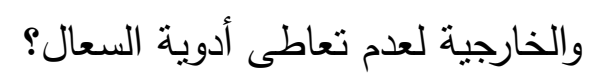

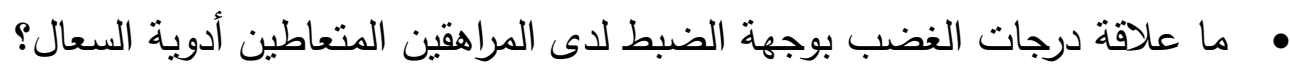

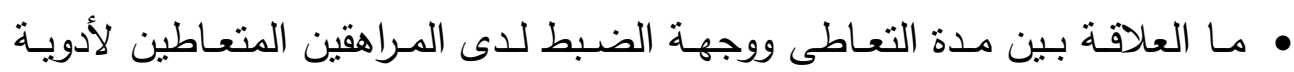
السعال؟ • ما العلاقة بين عدد مرات التعاطى ووجهة الضبط لدى المراهقين المتعاطين لأدوية السعال؟ • ما العلاقة بين مدة التعاطى ودرجات وأثكال الغضب لدى المراهقين المتعاطين

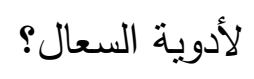

• مـا العلاقة بين عدد مرات التعاطى ودرجات الغضب لدى المراهقين المتعاطين

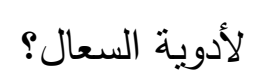

• مـا الأسـاليب والإجراءات التىى يمكن اتخاذها لعـلاج ظاهرة إسـاءة استخدام أدوية السعال المخدرة وتحول استخدامها إلى تعاطى لدى المراهقين؟ 


\section{خاهسا: الإطار المفاهيهى للدراسة}

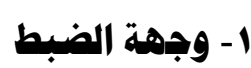

تعددت الكفاهيم السيكولوجية والاجتماعية لوجهة الضبط والتى تبلورت بارتباط وجهة

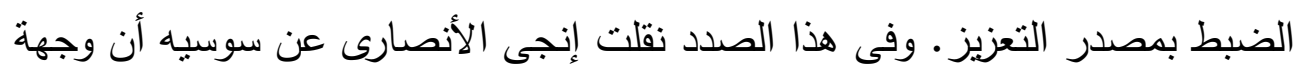

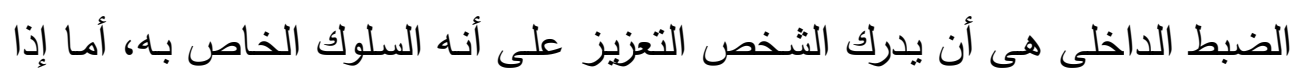

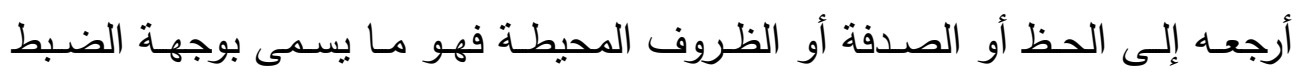
الخارجى (Sosis, 1974, p. 390).

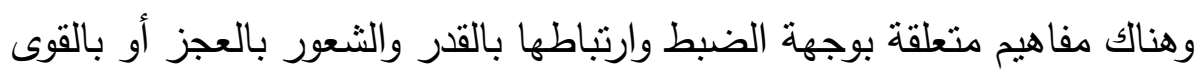

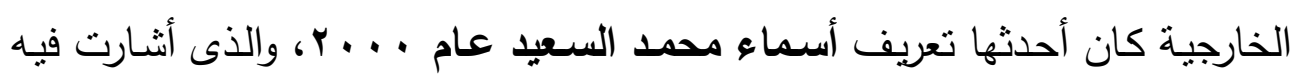

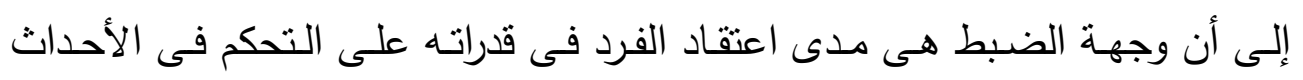

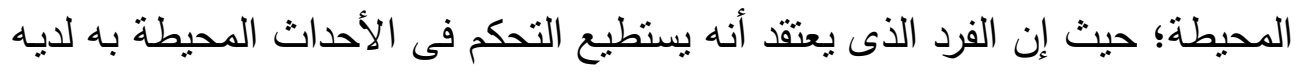

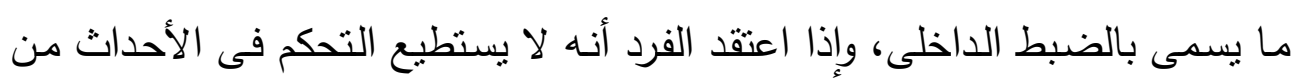

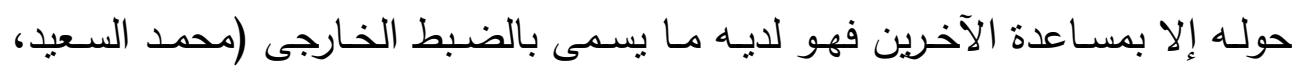

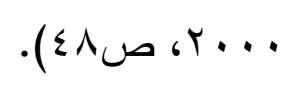

| - النغضب

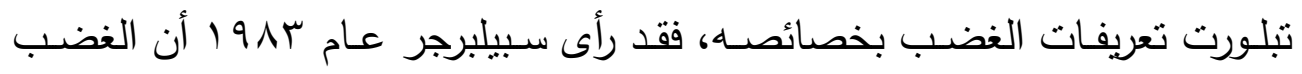

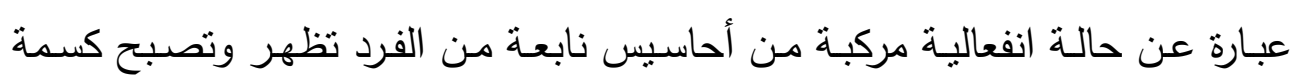

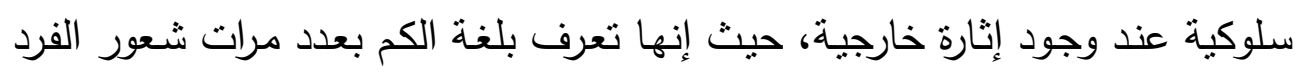
بالغضب استجابة للمواقف والمثيرات الخارجية (Spielberger, 1983).

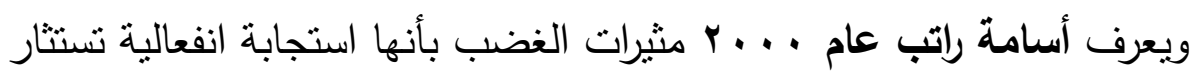

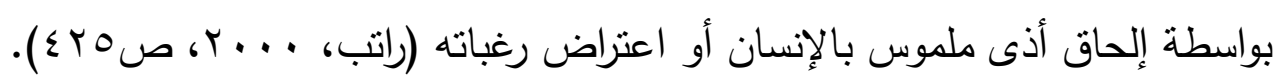


أنشار إبراهيم وجيه محمود أن المراهقة من أخطر المراحل التى يمر بها الإنسان فى

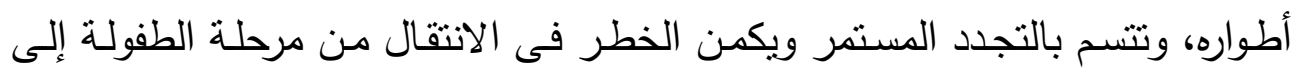

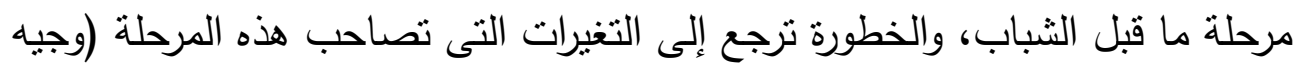

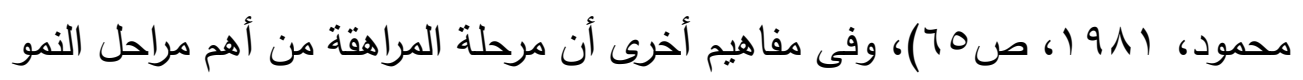

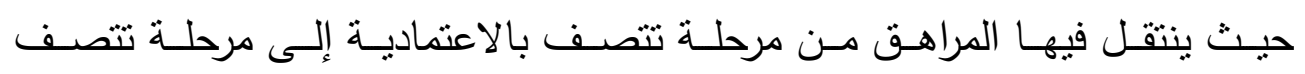

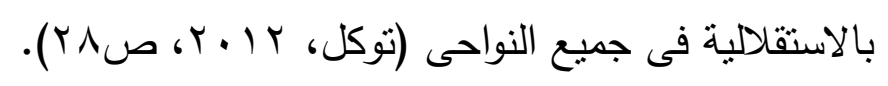

§- المتعاطى

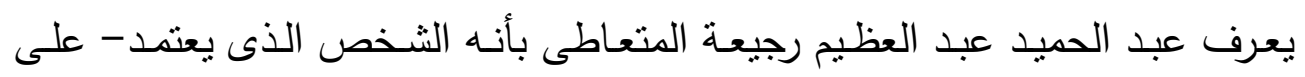

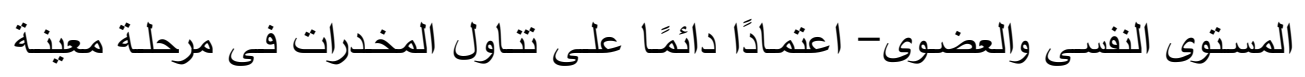

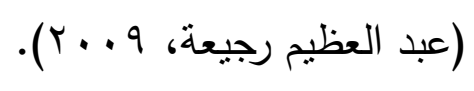

\section{ه- أدوية السعال}

السـعال انعكاس ودفـاع طبيعى يقوم بــه الجسم للتخلص مـن الكحـة عبر الممـرات

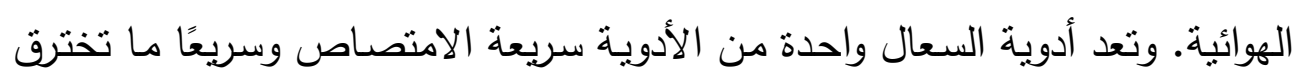

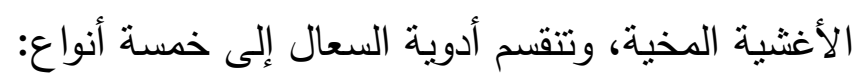
النوع الأول، الثراب المحتوى على مسكن للسعال، ومنها: 1 - بخدرة منل الثراب المحتوى على الكودايين.

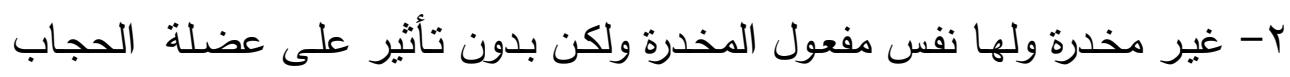

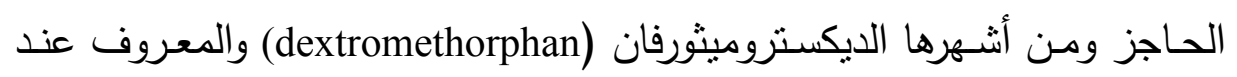

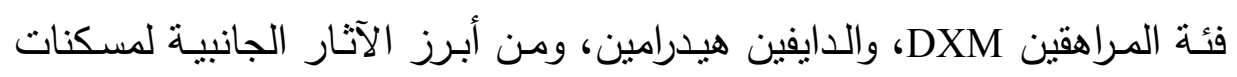


السعال سواء المخدرة منها أو غير المخدرة الثعور بالنعاس المستمر لذا يجب تجنبها أثناء فترة النهار .

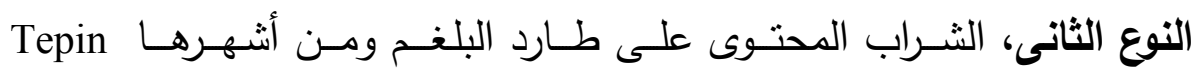
Guaifansin \& hydrate النوع الثالث، الثراب المحتوى على مذيب للبلغ ويختلف عن الثراب الطارد

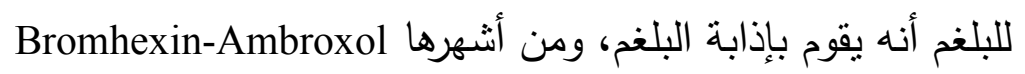
النوع الرابع، الثراب المحتوى على مزيل الاحتقان وأبرز أنواعه السودوفيدرين. النوع الخامس، الثراب المحتوى على المنتجات الطبيعية.

\section{1- - إساءة استخدام أدوية السعال}

إن استخدام أدوية السعال بالجرعة الصحيحة ووفقًا لتعليمات الطبيب لا ينتج عنها أية البهال

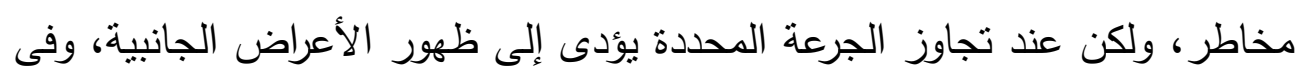

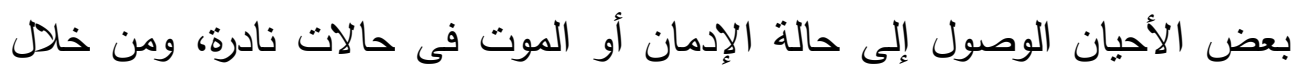

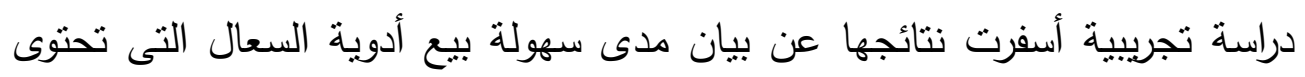

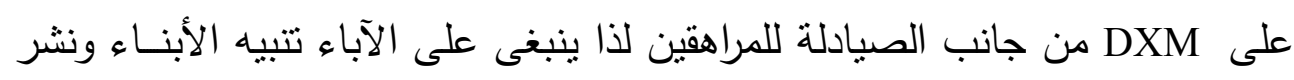

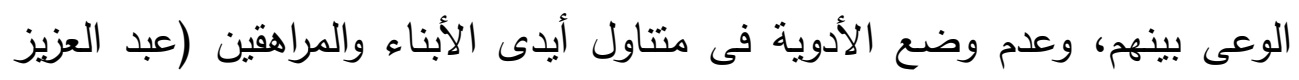

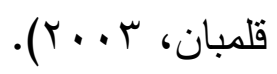

\section{سادساً: الإطار النظرى للدراسة}

ا - وجهة الضبط الإطار

تلعب وجهـة الضبط الداخليـة والخارجيـة دورًا فى مقاومـة تعـاطى الأدويـة والعقاقير

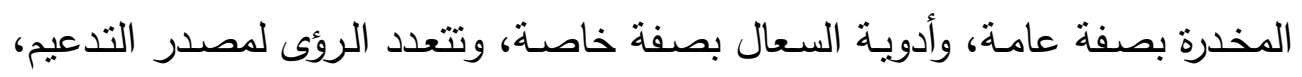

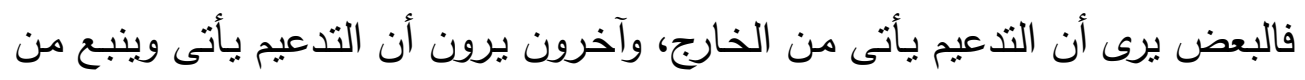
الداخل. 
وفى هذا الصدد اهتم روتر فى تتاوله لمفهوم وجهة الضبط بطرح الفروق بين

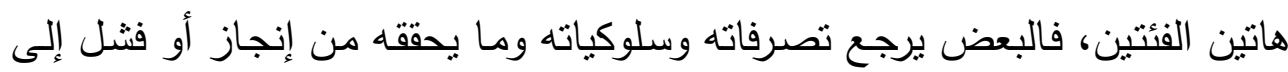
أسباب داخلية المصدر مثل القدرة والجهد؛ حيث إن إدراك الفرد للأحداث يكون متفقًا

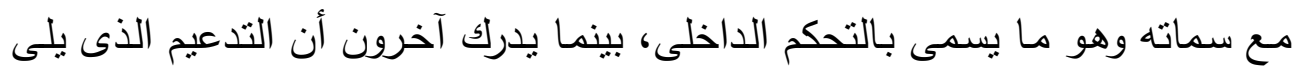
سلوكياته وأفعاله الثخصية أمر مستقل وغير مرتبط بالقدرات فيرجعه دومًا إلى عوامل

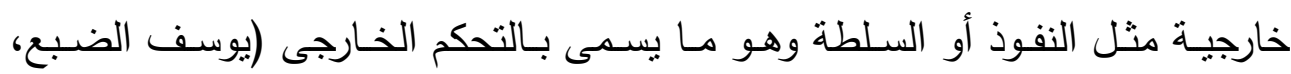

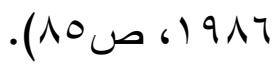

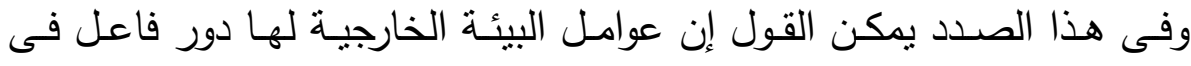
تشكيل وجهة الضبط الداخلية/ والخارجية لدى المراهقين المتعاطين لأدويـة السعال، لهال حيث إن العوامل الخارجية لعبث دورًا.

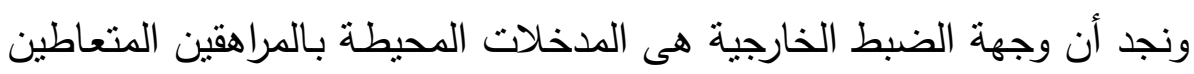

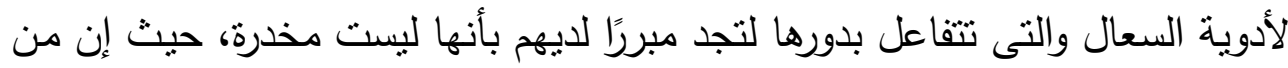

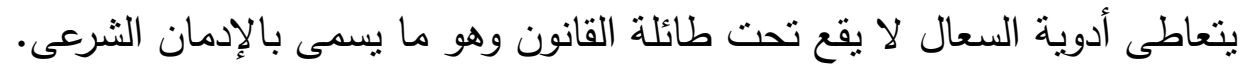

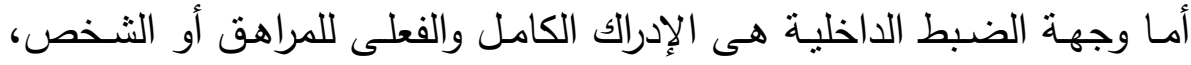

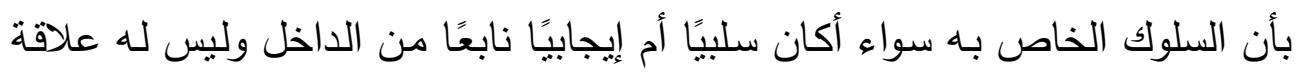
بتغيرات خارجية (Sosis, op. cit, p. 393). وهنـاك العديد مـن السـمات المميزة للأثـخاص ذوى الضبط الداخلى فهم لا لا يميلون لمقاومـة تأثثير من حولهم فقط، بـل يميلون إلى التحكم فى سلوك الآخرين

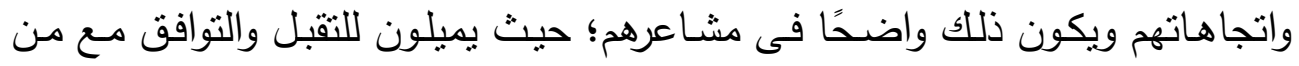

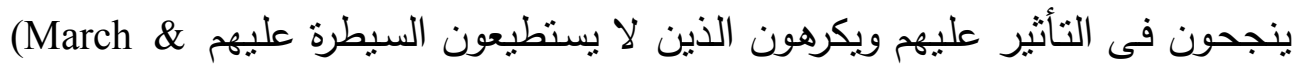
.Richards, 1989, p. 521) 
أمسا الأثخخاص من ذوى الضبط الخـارجى فيتميزون بالسلبية وقلة المشاركة،

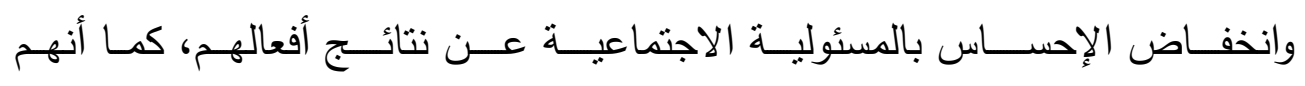

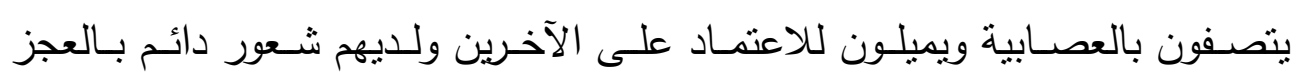
والضعف (Freedaman, 1991, p. 32).

وترتبط وجهة الضبط ببعض المتغيرات كمـا أثنـارت العديد مـن الدراسـات، منها:

أ- الذك

يعد الذكاء من العوامل التى لها علاقة مباشرة بوجهة الضبط؛ حيث أكد متخصصون

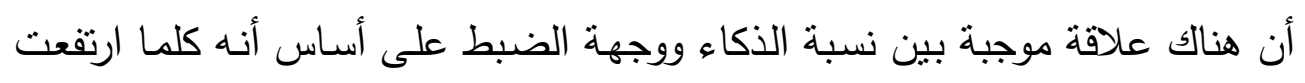

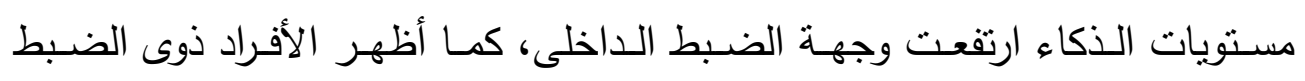

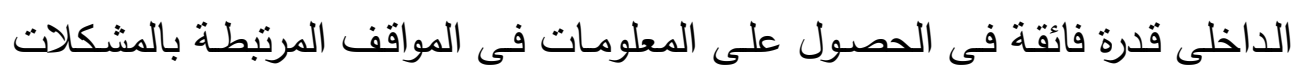

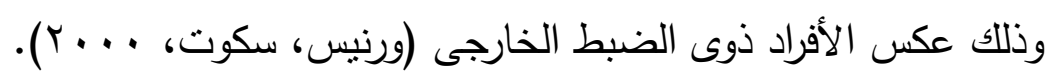

يعد السن متغيرًا مهمًا ولهـ دور فاعل فى تحديد وجهة الضبط، فإن معايثـة الفرد

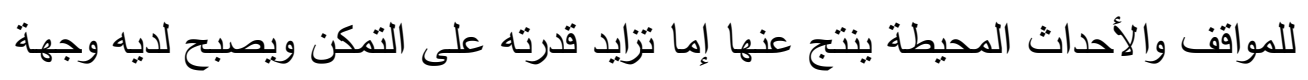

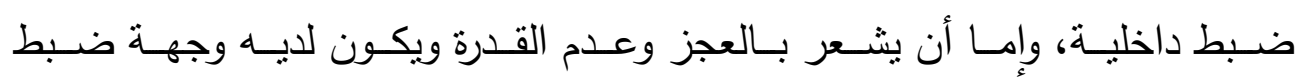
خارجية(Freedaman, op. cit).

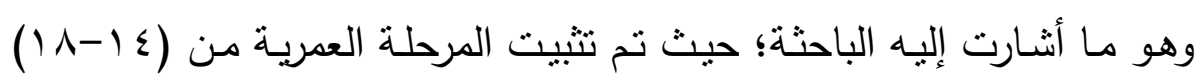

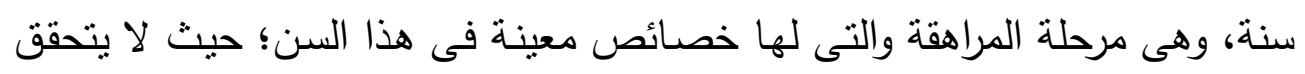
التوافق فى هذه المرحلة إلا بعد حدوث توافق مع النضج الجنسى والبيولوجى والتغيرات المنوطة بهذه المرحلة. 


\section{ج - المستوى الاقتصادى/ الاجتهاعى / الثقانى}

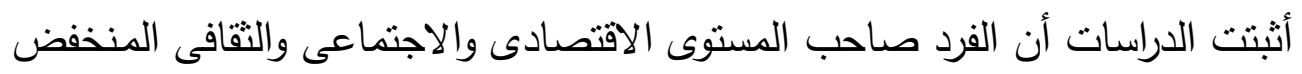

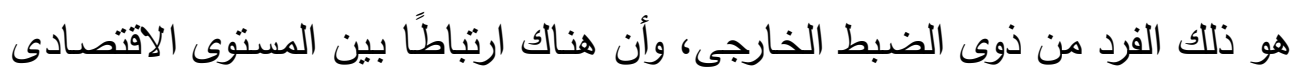

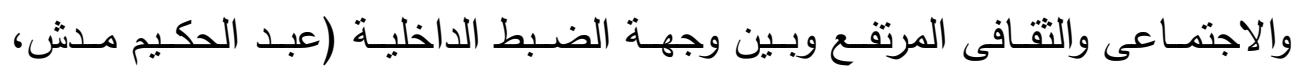
.$(1991$

\section{د- الأسسرة}

أوضحت دراسـة نيفين زهران (r . . r) أن الضبط الداخلى يزداد لدى الأفراد الذين

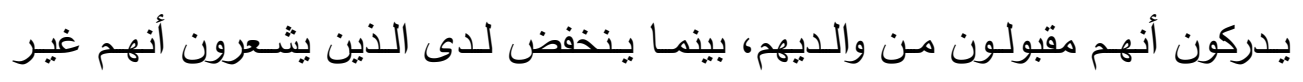

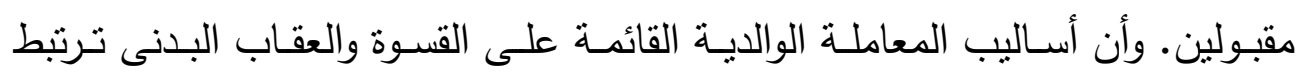
ارتباطًا موجبًا بوجهة الضبط الخارجية (محمد زهران، ب. . بr).

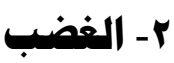

تعرف حالة الغضب بأنها حالة انفعالية تتكون من أحاسيس ذاتية وتتضمن التوتر

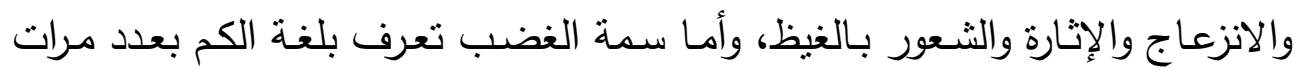
شعور الفرد بالغضب فى وقت محدد، والثخص الذى ترتفع عنده سمة الغضب يميل للاستجابة لكل المواقف بالغضب.

وقد أكد علاء كفافى ومايسة النيال أن الغضب استجابة انفعالية تحدث نتيجة

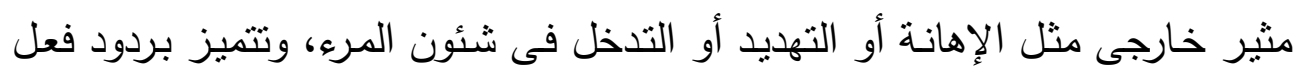

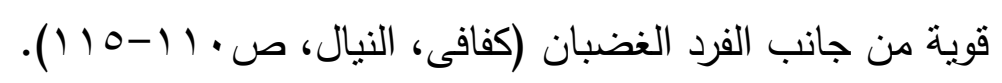

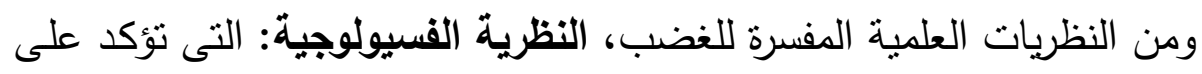

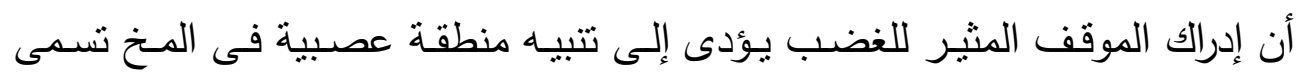

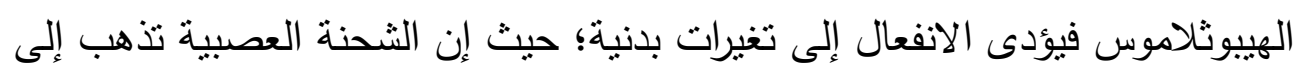


القشرة الدماغية فينشأ الثعور بالغضب، بينما تذهب بعض المثيرات إلى الـخ حيث

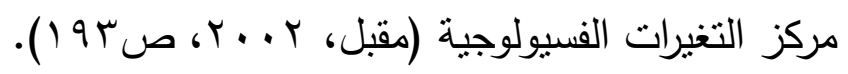

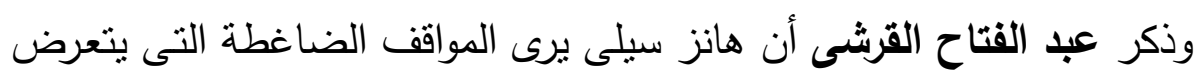

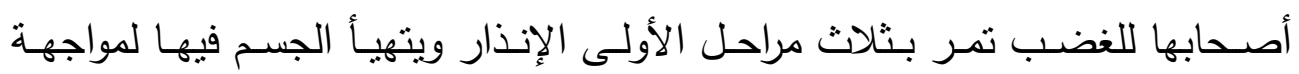

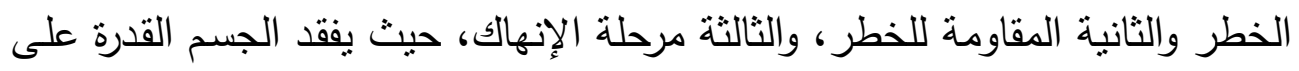

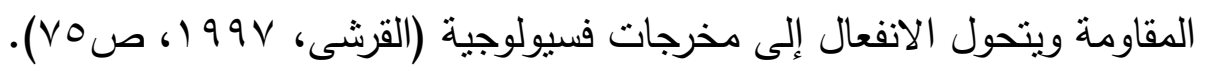

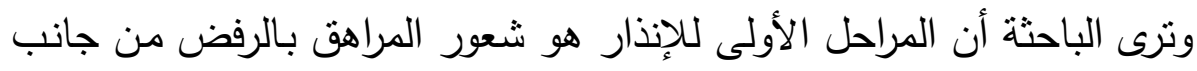

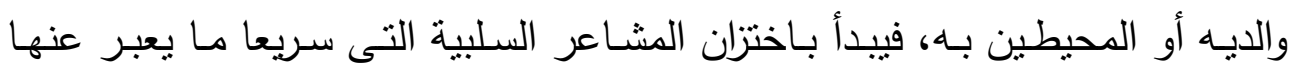
بالانفعال الزائد والعنف والغضب.

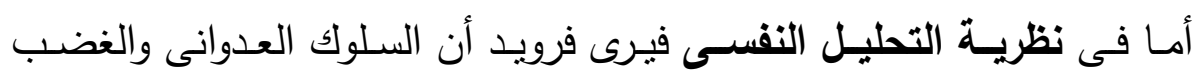

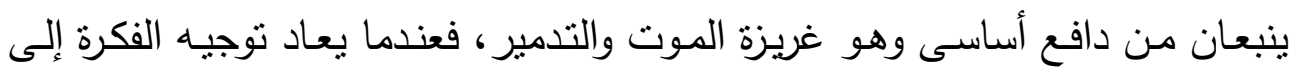

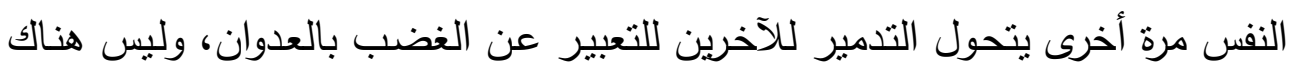

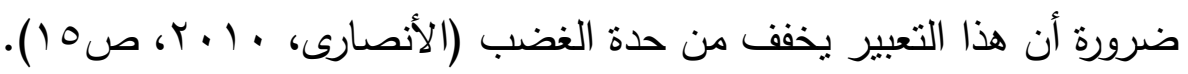

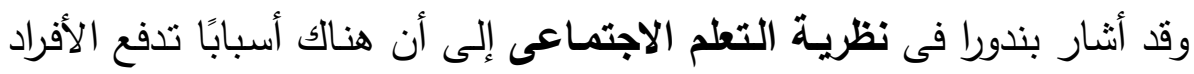

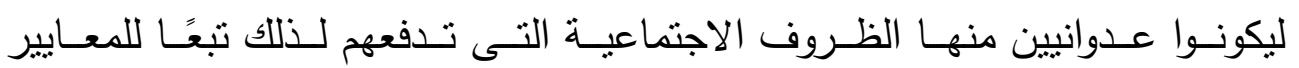

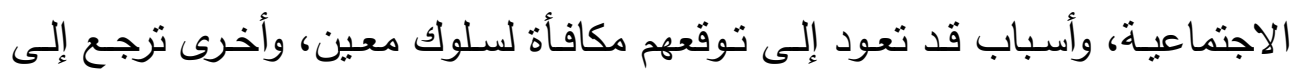

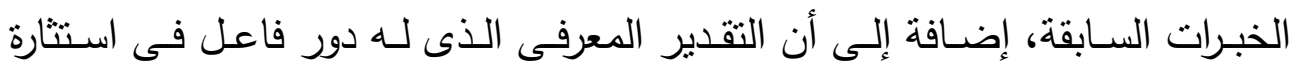

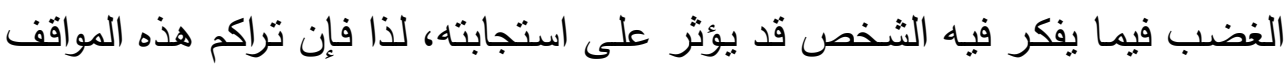

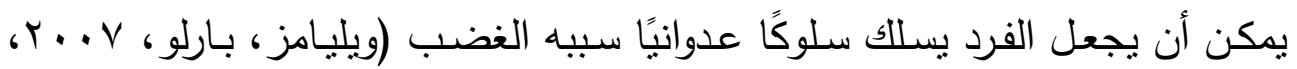

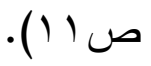

وتتتوع الأسباب المؤديـة للغضب فمنها أسباب صحية وجسمية؛ فقد تسبب الإصـابة بأى مرض بدنى التوتر نتيجـة الثـعور بالضعف العام، وتؤثثر التشوهات 
الخلقية على النقة بـالنفس وهى إحدى الإصـابات الصحية التـى تسـبب الغضـبـ .(Lao \& Chuamge. Op. cit) وقد أثنار جنترى إلى العوامل الاجتماعية كسبب من أسباب الغضب؛ حيث إن

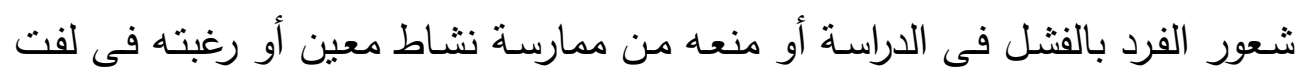

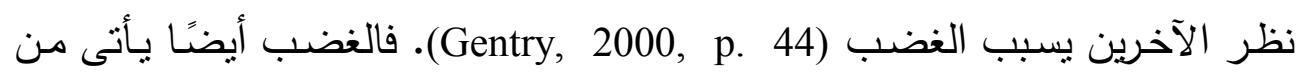

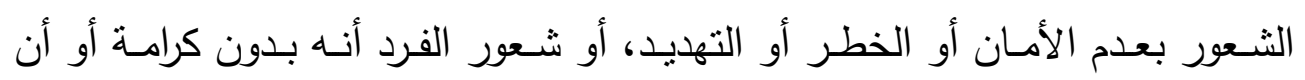
معاملة الآخرين له غير عادلة.

كما تتذاخل العوامل الثخصية مثل مسنوى الذكاء وشخصية الطفل وسلوكياته

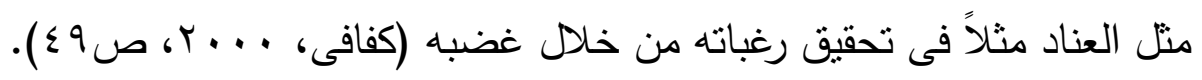

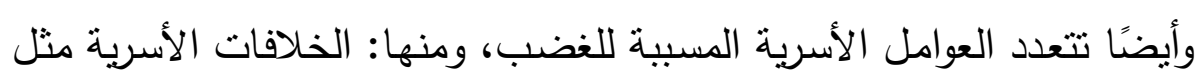

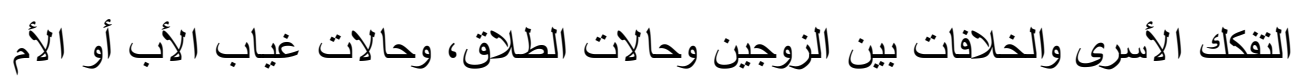

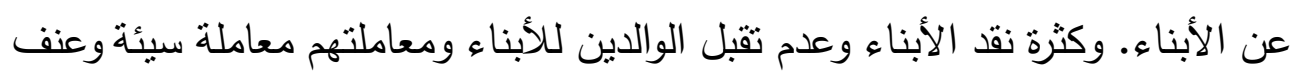

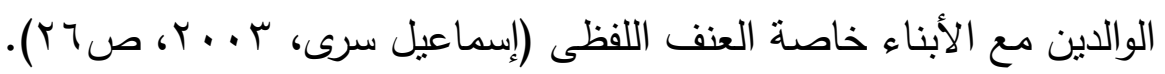

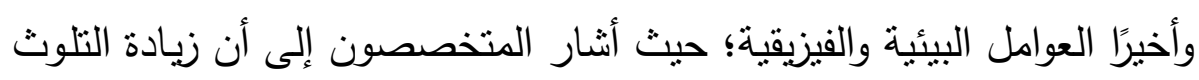
أحد عوامل الاستتارة العالية للغضب (Benson \& Fushs, 1999)، والتأثنرات السلبية

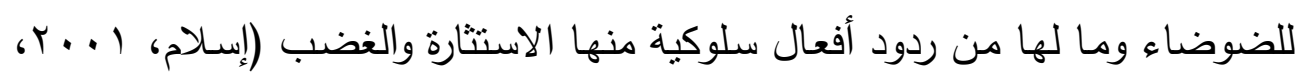

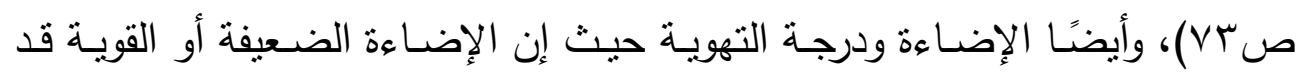

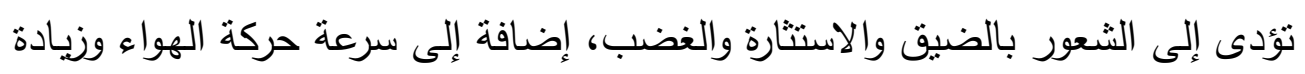

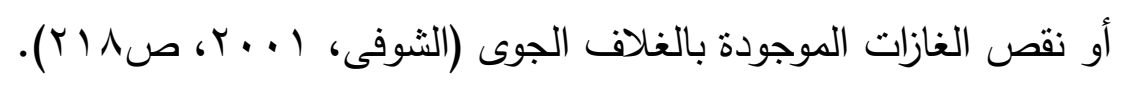

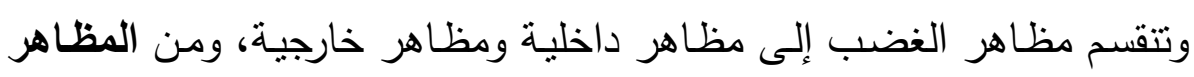
الاخلية للفضب عدة تغيرات فسيولوجية نتاج أوامر من مراكز المخ كرد فعل لاستثارة

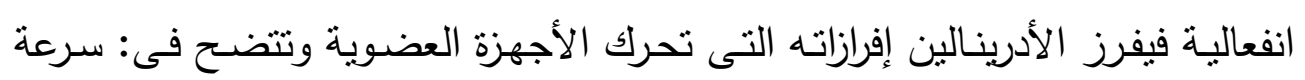


ضربات القلب - ارتفاع ضغط الدم - سرعة التنفس - اضطراب الجهاز الهضمى. كما أضافت كرستين ازدياد تجلط الدم وارتفاع نسبة السكر ووجود تغيرات كيميائية

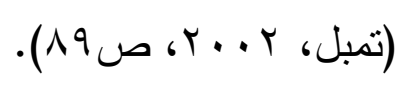

ومن المظاهر الخارجية للغضب: الثعور بالأرق، واضطراب النوم، والصراخ،

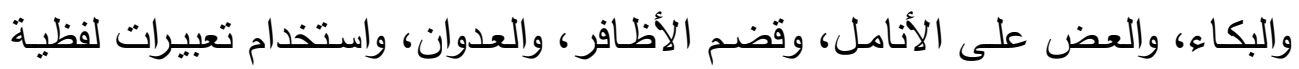

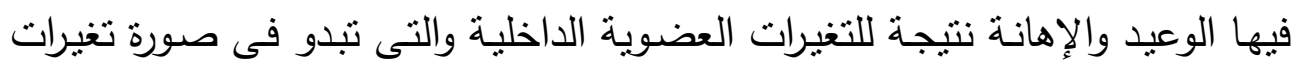

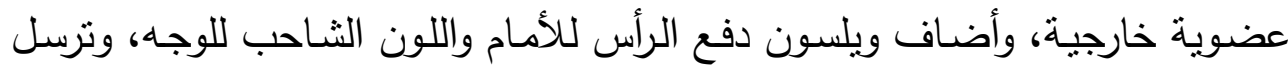

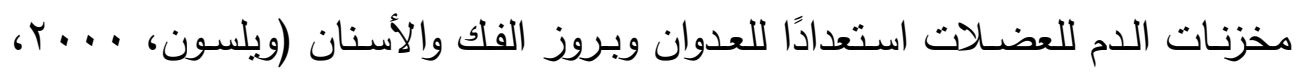

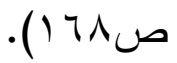

$$
\text { والغضب نوعان، غضب سلبى وينقسم إلى: }
$$

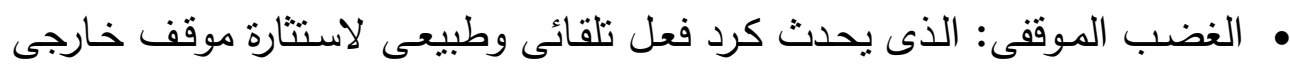
كما براه جولمان؛ حيث يكون مصحوبًا بتغيرات فسيولوجية وأخرى خارجية تتبلور

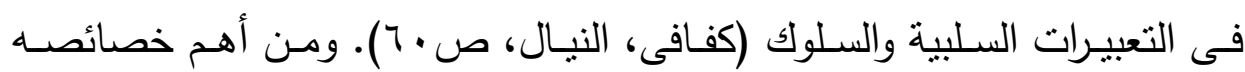
العدوان الموجه نحو الذات، والعدوان المدمر الموجه نحو الآخرين ويتنم بالحدة العدات وطول المدة وزيادة عدد مرات الغضب. • الغضب الانسحابى: ويكون كما وصفه وليد مراد فى شكل انطواء وانزواء بعيدًا عن الآخرين (مراد، مرجع سابق).

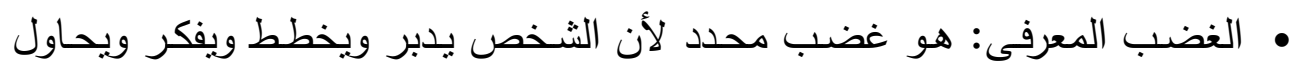

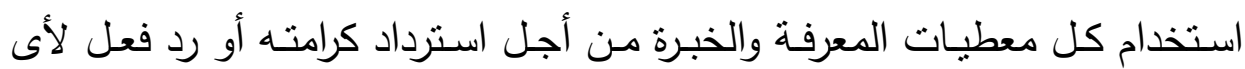

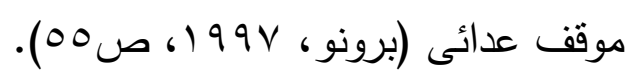


• الغضب المزمن: سببه عدم التوافق النفسى للفرد، ويتميز بخصائص منها المرض

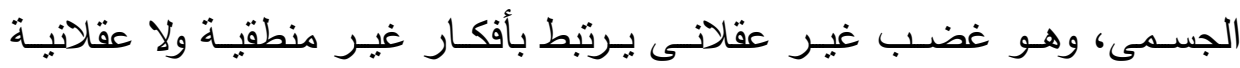

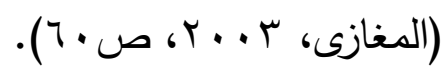

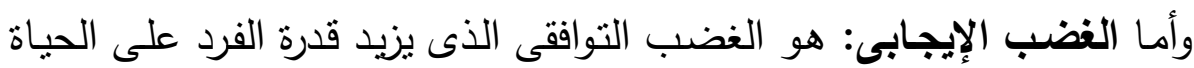
بشكل أفضل وله أثنكاله المتعددة: • الغضب التنظيمى: يخدم العديد من الوظائف التوافقية التى تشمل تنظيم العمليات الفسيولوجية والنفسية ذات العلاقة بالدفاع عن الذات بالسيطرة وتنظيم السلوكيات الاجتماعية. • الغضـب التعـاطفى: هو مـا أطلاق عليـه سـتيورات حـارس العدل؛ حيث يحدث الغضب كنوع من المشاركة الوجدانية مع الآخرين.

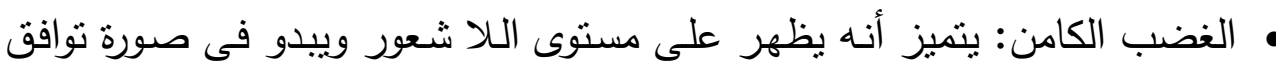

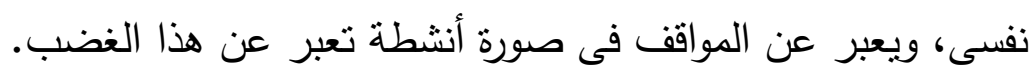

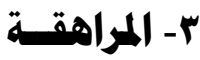

تكون مرحلـة المراهقة إمـا مراهقة سوية وتكون خالية من المشكلات، وإمـا مراهقة انسحابية حيث ينسحب المراهق من مجتمع الأسرة والأقران ويفضل الانعزال والانطواء

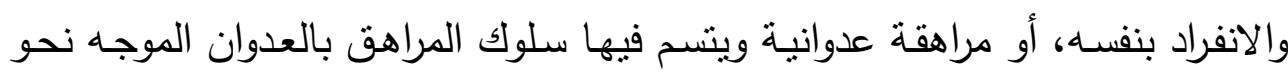
نفسه والآخرين، ويكون السبب فى هذا السلوك بعض التغيرات البيولوجيـة والنفسية

$$
\text { التى نطرأ فى هذه المرحلة. }
$$

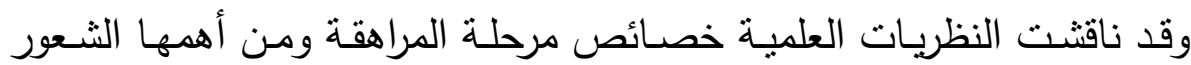
بالاستقلالية؛ حيث يسهم المجتمع فى وضع ضغوط كثيرة على المراهقين ويفتشل فى لى

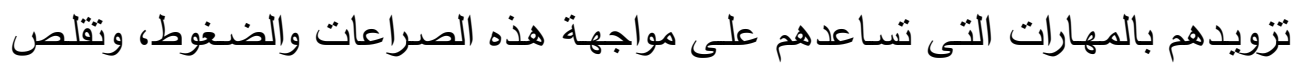


رغبة المراهق فى تحقيق الاستقلال الذاتى والاعتماد على النفس من خلال علاقاته

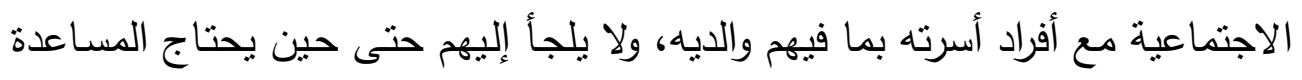

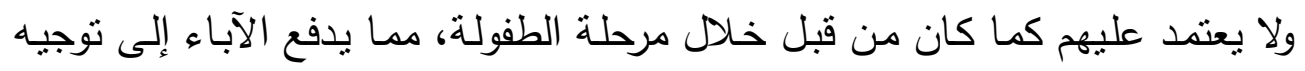

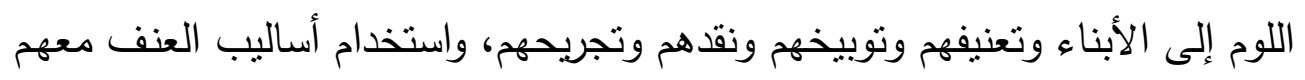

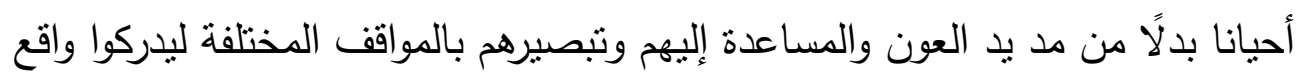

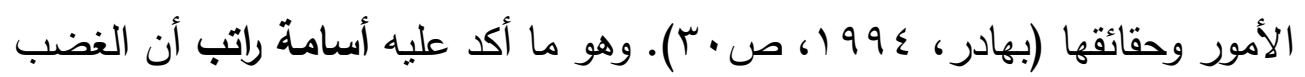

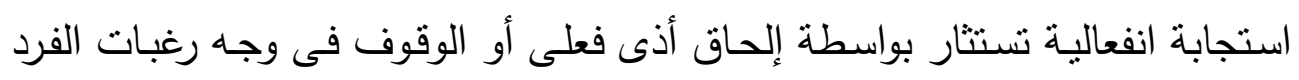

$$
\text { (راتب، مرجع سابق). }
$$

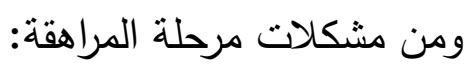

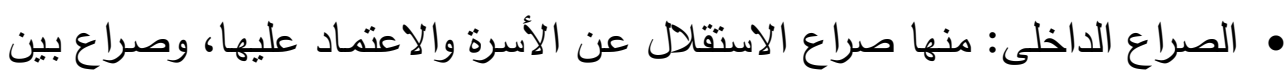

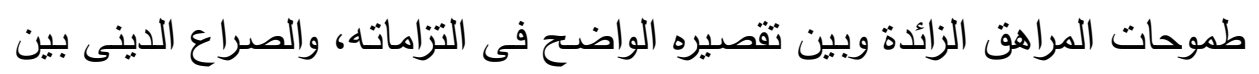
ما تعلمه من شعائر ومبادئ ومسلمات وهو صغير وبين تفكيره الناقد الجديد.

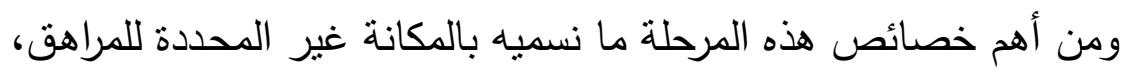

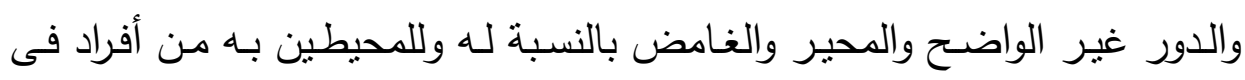

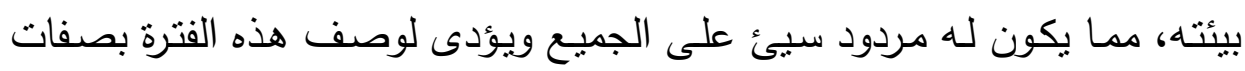

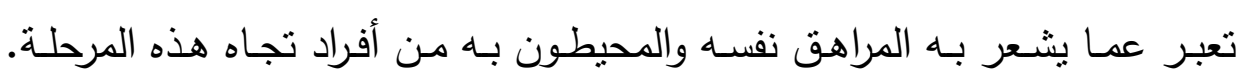

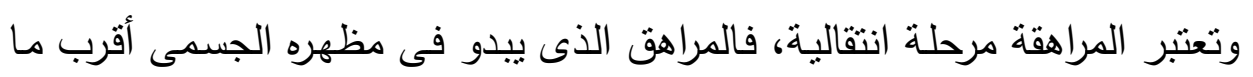

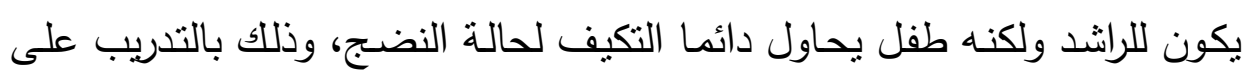

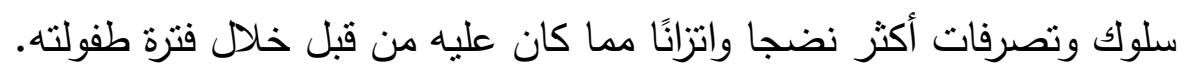

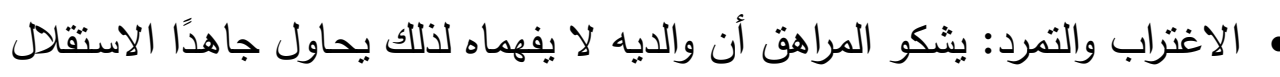

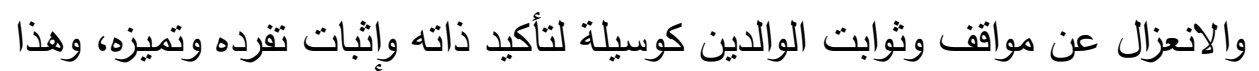
بستلزم معارضة سلطة الأسرة. 


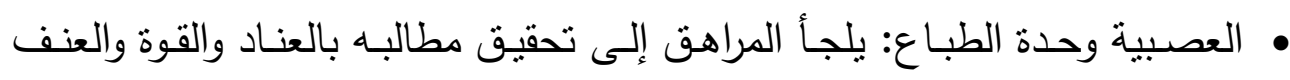

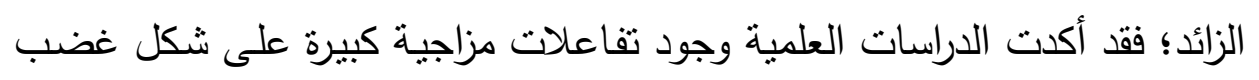
وإثارة وحدة طباع (Vedvarma, 1996, p. 103).

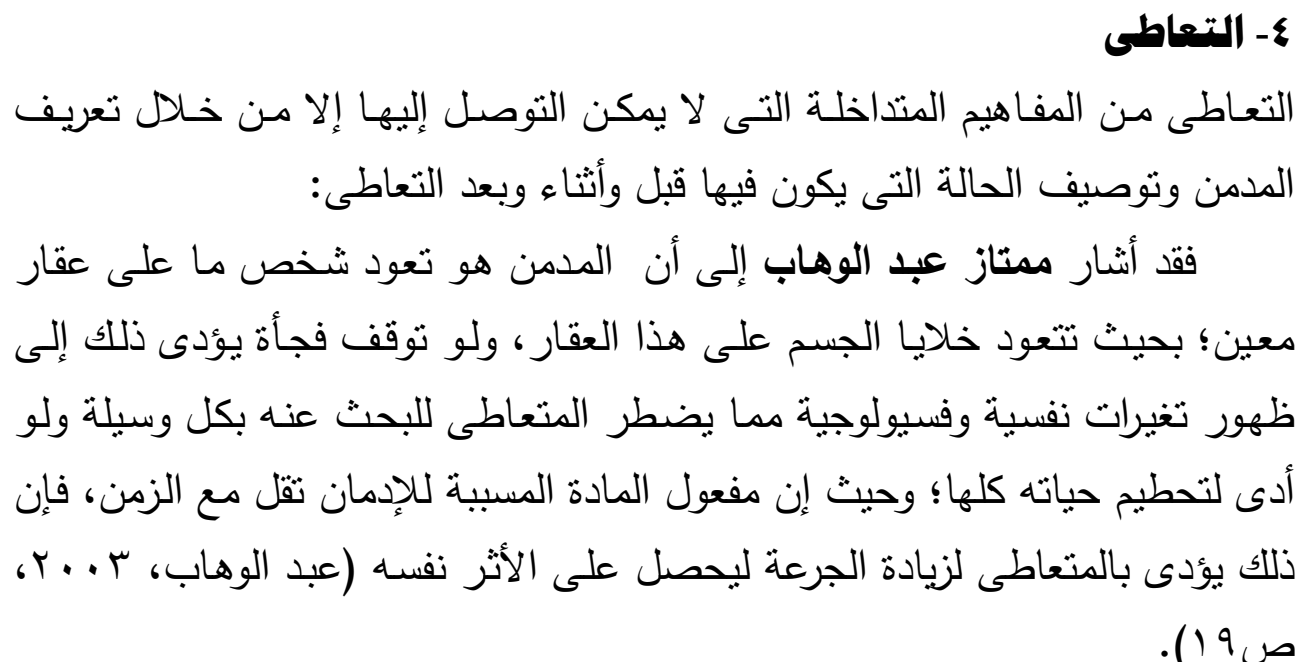

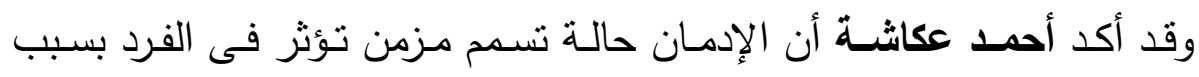

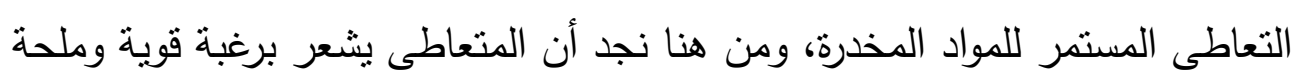

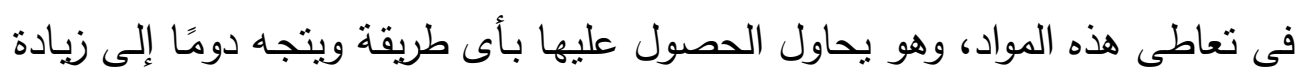

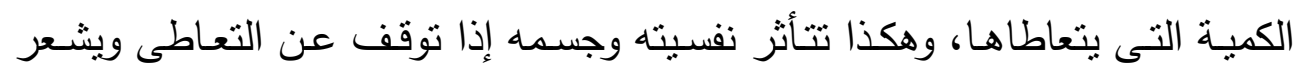

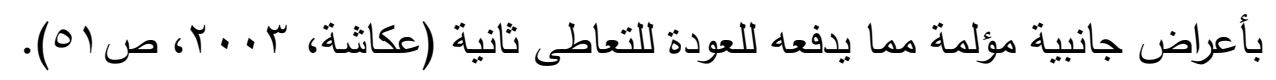

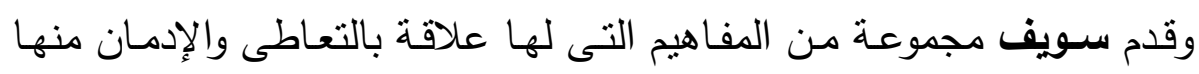

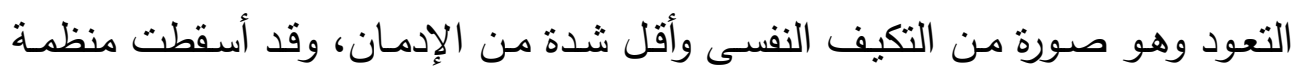

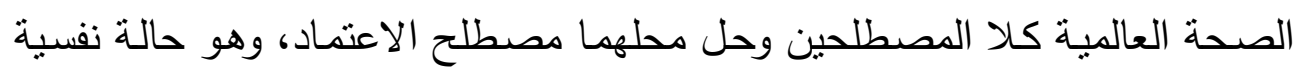

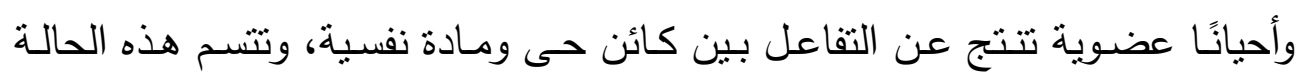

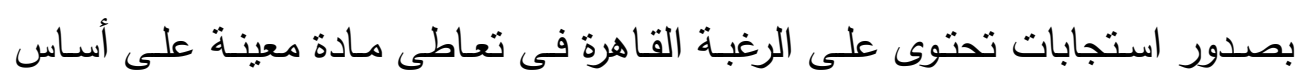
مستمر (سويف، مرجع سابق). 
وجدير بالذكر أن الاعتماد النفسى يبدأ عندما يبحث المتعاطى عن الهخدر

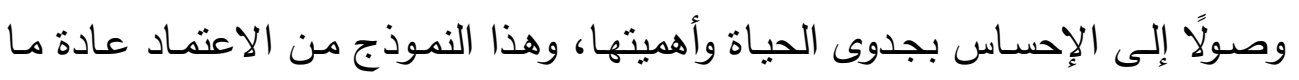
يكون متغيرًا تابعًا لتغير الحدث بين المادة والمتعاطى.

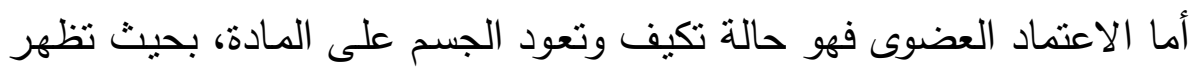
على المتعاطى اضطرابات نفسية وعضوية عند امتتاعه عن تتاولها فجأة (سويف،

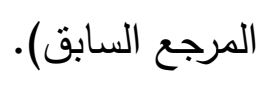

وهنـاك العديد من مظاهر السلوك المتعلقة بظاهرة الاعتماد على العقاقير مثل:

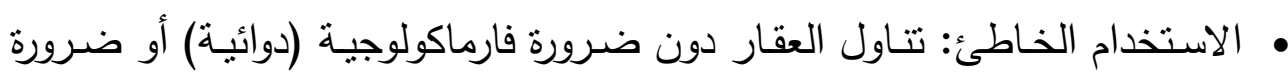

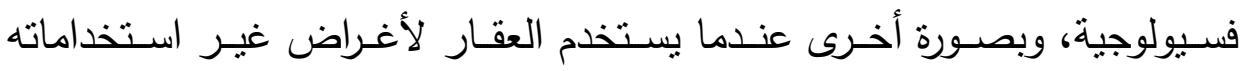
المخصصة طبيًا.

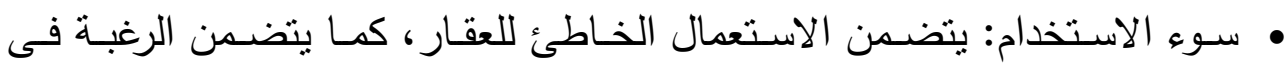

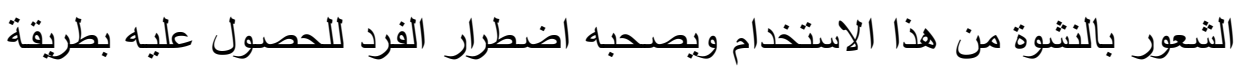

$$
\text { غير مشروعة. }
$$

• الجرعـة الزائدة: هـى الجرعـة التى تزيد على الجرعـة المقنـة، ويحدث لها آتار معاكسة وحادة بصفة مؤقتة.

\section{النظريات المفسرة للتعاطى وشخصية المتعاطى}

1- وجهة النظر الفسيولوجية والبيولوجية

يوجد على جدار الخلايا العصبية مجموعة من المستقبلات التى تعمل على اسنقبال العقاقير، وأن لكل مستقبل مادة خاصة به يستقبلها دون غيرها، ونتيجة تفاعل العقار

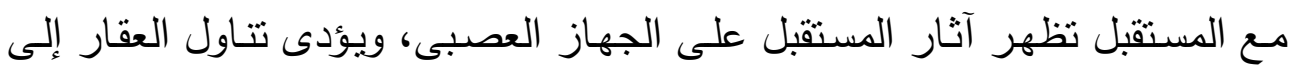

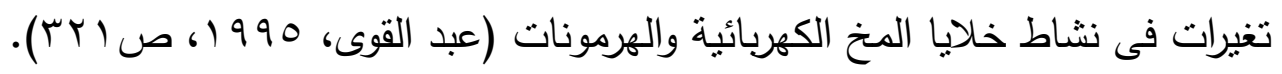




\section{r- النظرية السلوكية للإدهان}

تفترض هذه النظريـة أن تعـاطى المخدرات وإدمانها سلوك يتعلمـه الإنسـان (نظريـة

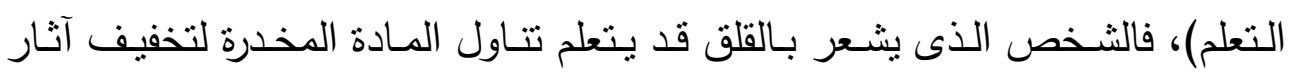

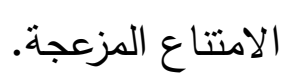

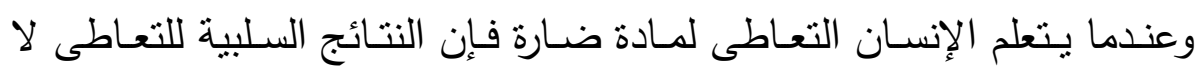

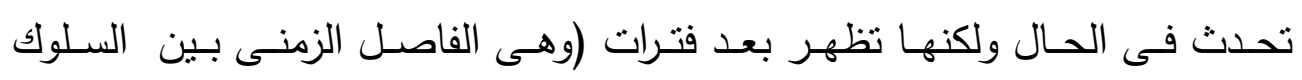

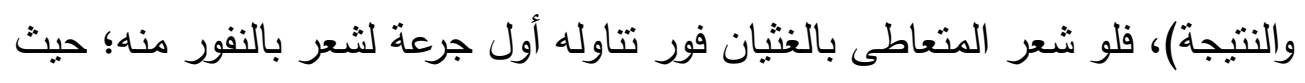

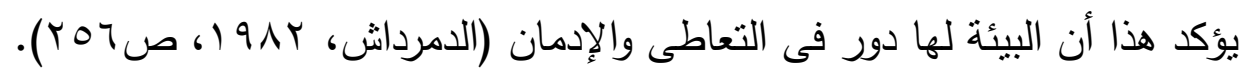

\section{r- نظرية التحليل النفسى}

يفسر التحليل النفسى أن ظاهرة التعاطى ثرجع فى أساسها إلى اضطراب العلاقات بين الدمن ووالديه، ويتضمن ذلك ثثائية فى العاطفة أى الحب والكره معا للوالد مثناً،

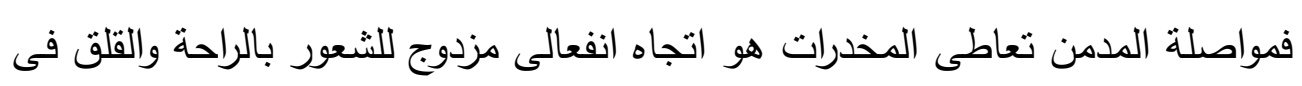
الوقت نفسه.

\section{ع- النظرية الاحتهاعية}

أكد المغربى أن هناك العديد من العوامل المادية والاجتماعية والنفسية مثل الأساليب

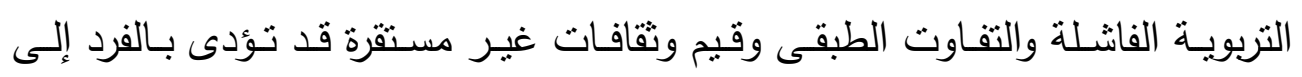

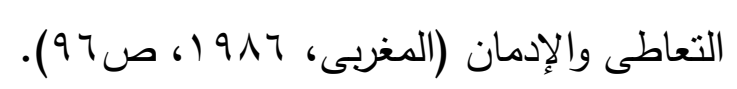

\section{سابعاً: فروض الدراسة}

1- نوجد علاقة ارتباطية دالة إحصائًاً بين درجة الغضب ورجهة الضبط الداخلية والخارجية لاى المراهقين الكتعاطين أدوية السعال. 
r- توجد علاقة ارتباطية دالة إحصائيًا بين أنشكال الغضب ووجهة الضبط الداخلية والخارجية لاى المراهقين المتعاطين أدوية السعال.

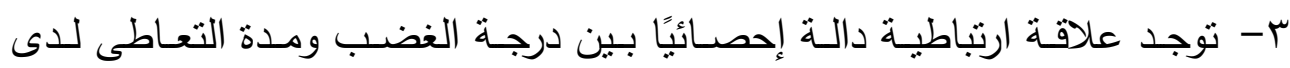
المراهقين المتعاطين أدوية السعال.

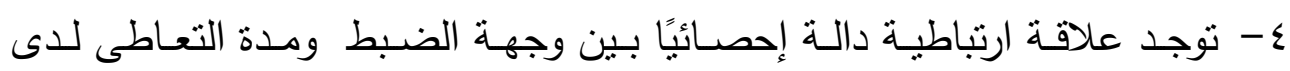
المراهقين المتعاطين أدوية السعال.

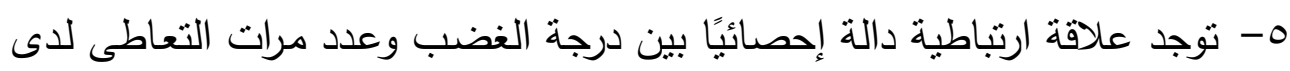
المراهقين المتعاطين أدوية السعال. 7- توجد علاقة دالة إحصائيا بين وجهة الضبط وعدد مرات التعاطى لدى المراهقين المتعاطين أدوية السعال.

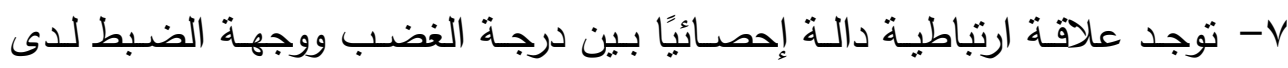
المراهقين المتعاطين أدوية السعال.

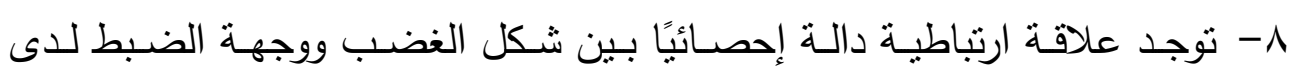
المراهقين المتعاطين أدوية السعال.

\section{ثاهنا:الإجراءات المنهجية}

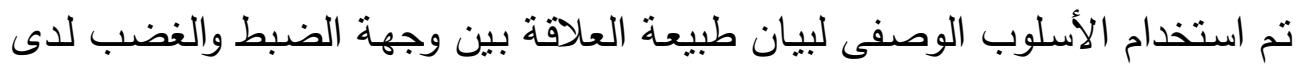

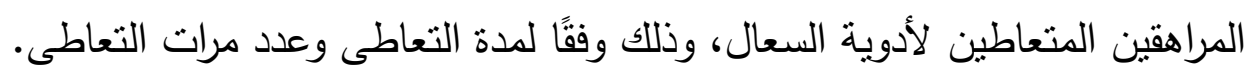
| العينة - العتبار

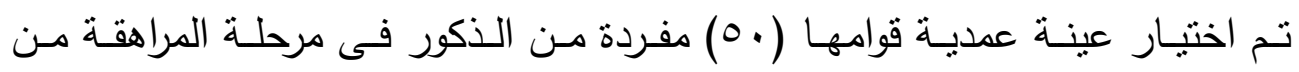

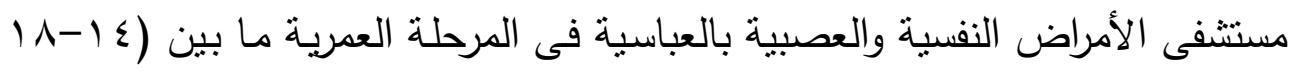

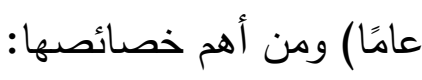


• عينة من الذكور المراهقين الخاليين من أية إعاقات أو تشوهات خلقية، ويكون ذلك بالرجوع إلى تاريخهم المرضى والاطلاع عليه بمستتفى العباسية.

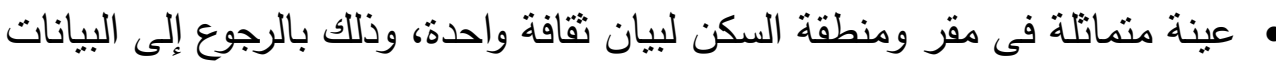
الاجتماعية للمراهقين المتعاطين أدوية السعال المسموح بها طبيًا.

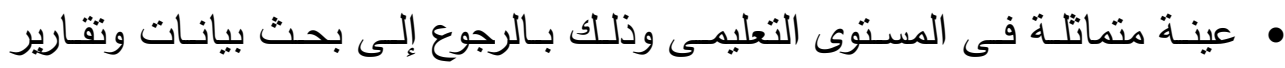
المدرسة إن وجدت أو تقرير المستشفى. • عينة متماتلة فى المستوى الاجتماعى والاقتصادى بالرجوع إلى دراسة الحالة التى لتى

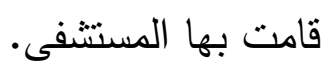

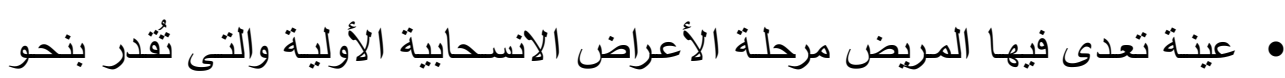
أسبوعين على الأقل وذلك بالرجوع إلى التقارير الطبية.

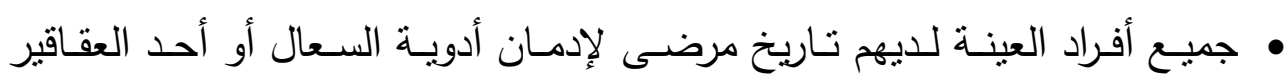
المخدرة (حيث يكون خضع للعلاج مدة لا تقل عن ثمانية أشهر فأكثر ).

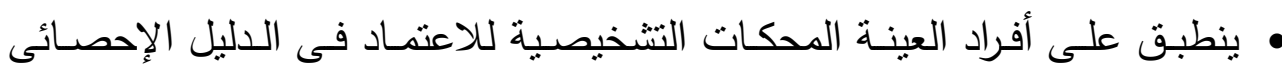
للأمراض النفسية.

\section{الصعوبات الميدانية}

قد ثم الحصول على العينة فى بادئ الأمر من بعض مراكز الثباب ولم تُحقق جدوى

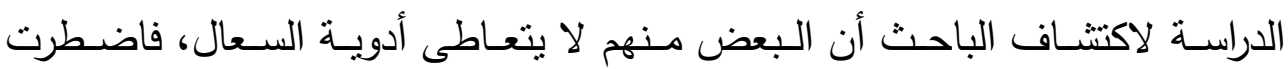

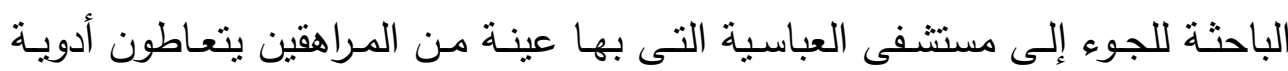
السعال بصورة أساسية وبعض العقاقير الأخرى ولكن ليس بصورة اعتبادية، وخلال العمل تعرضت الباحثة للعديد من الصعويات منها: • عدم الحصول على عينة الدراسة بسهولة. • عدم الجدية من بعض عينة الدراسة فى الاستجابة للباحث. 
• صعوبة التعامل مع المؤسسات القائمة على علاج المتعاطين (حجب المعلومات).

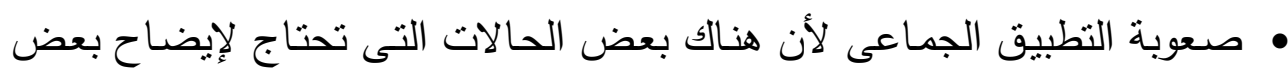
المعانى اللغوية فى المقاييس. • رفض العديد من الحالات الاستمرار فى التطبيق، مما أدى إلى خفض عدد العينة من · مفردة إلى ست مفردة.

r- r r r أدوات الدراسة استخدمت الباحثة عددًا من أدوات الدراسة: أ- استهارة جمع بيانات المتعاطين (إعداد الباحثة)

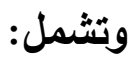

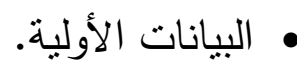

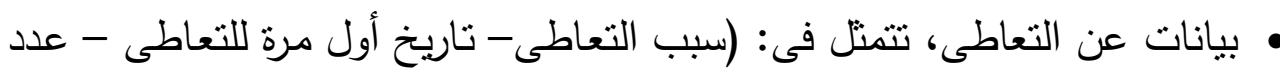

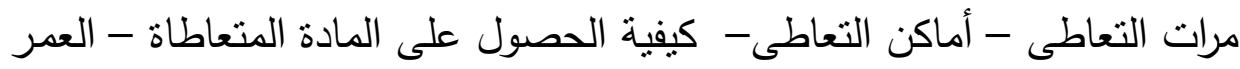
عند التعاطى - عدد محاولات التوقف عن التعاطى - أصدقاء التعاطى - كيفية الحصول على المادة المتعاطاة - أسلوب التعاطى - نمط التعاطى - هل هناك

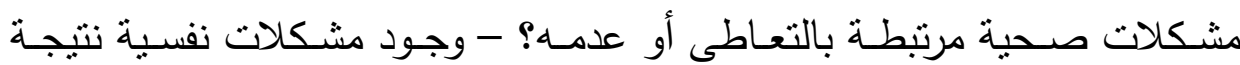
التعاطسى - تاريخ أول مرة محاولة للتوقف إن أمكن - عدد محاولات العلاج).

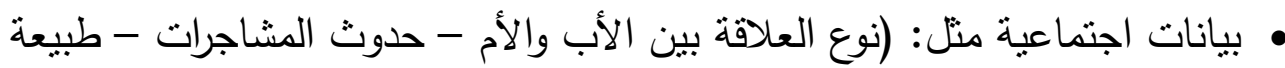
المشاجرات - عدد أفراد الأسرة - عدد الأصدقاء - دور الفرد فى الأسرة).

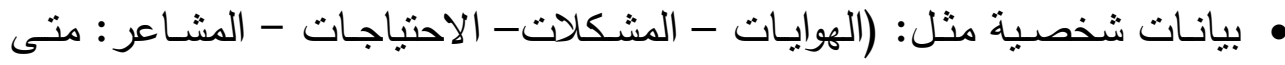
تشعر بالغضب؟ - طريقة الغضب - متى تبكى؟ - هل تتأثز بمشاعر أصدقائك؟ - من أكثر فرد يحبك؟ - من أكثر شخص يقدرك؟). 


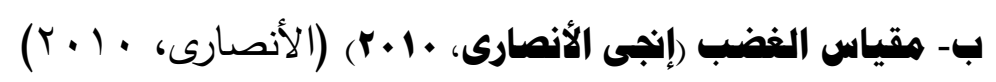

$$
\begin{aligned}
& \text { وأهم أبعاده: } \\
& \text { • ت تحديد مثيرات الغضب. } \\
& \text { • تكرار نوبات الغضب. } \\
& \text { • الأعراض النفسجمية للغضب. }
\end{aligned}
$$

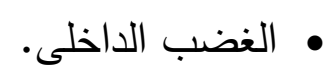

$$
\begin{aligned}
& \text { • الغضب الخارجى والسلوك الظاهر • }
\end{aligned}
$$

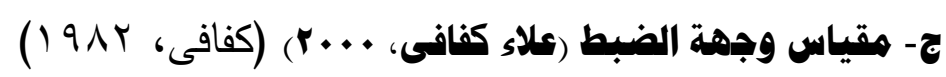

$$
\text { وأهم أبعاده: }
$$

• وجهة الضبط الداخلية.

• وجهة الضبط الخارجية.

r- إجراءات التطبيق

تم التطبيق جماعى فى مستشفى الأمراض النفسية والعصبية بالعباسية، وتم اختيار الحالات بالأسلوب العددى للتأكد من المرحلة، وأنهم يقطنون مناطق سكنية منماثلة بالإضافة إلى مرحلة تعليمية واحدة، مع التأكد من عدم وجود تاريخ مرضى باستثناء المصابين بالأمراض الصدرية سواء موسمية أو دائمة.

ع- الأساليب الإهصائية المستخدهة

(المتوسط الحسابى - الانحراف المعيارى - معامل ارتباط بيرسون). 


\section{تاسعاً: نتائج الدراسة}

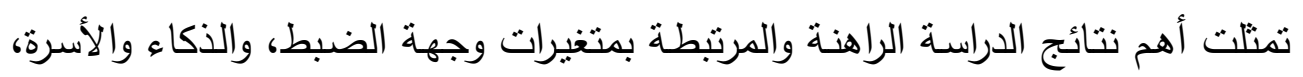
والغضب، والمراهقة، والتعاطى، فيما يلى أنى

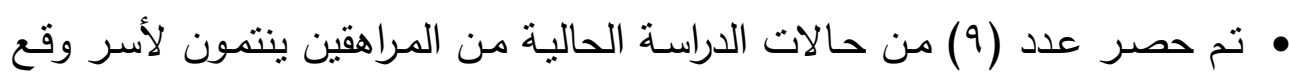

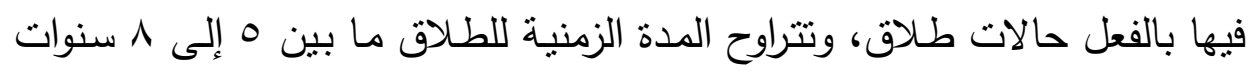

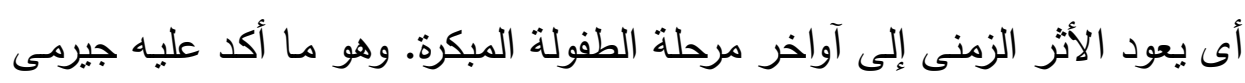

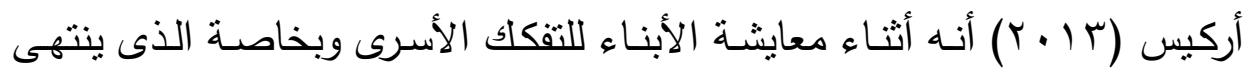

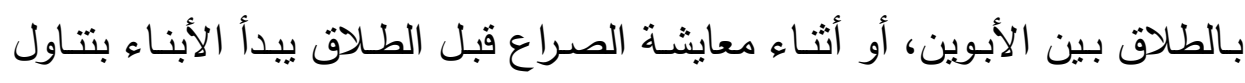

$$
\text { الكحول (أركس، مرجع سابق). }
$$

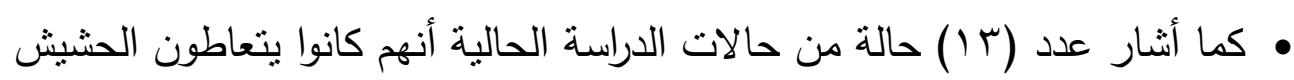

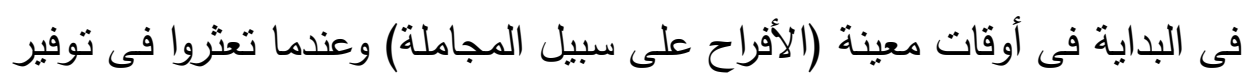

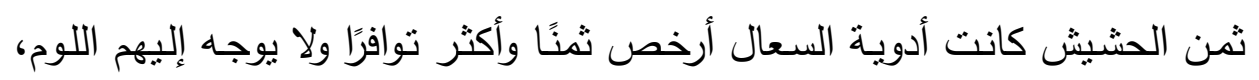
فالحشيش يعاقب عليه القانون أمسا أدويـة السعال المسموح بها طبيًا أكثر أمانًا

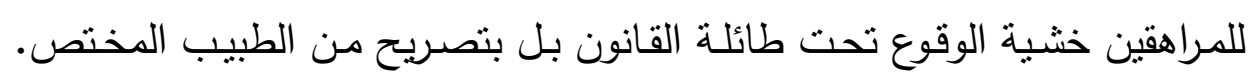
ونتائج الدراسة تثير إلى أن وجهة الضبط الخارجية المعتمدة على البيئة الخارجية

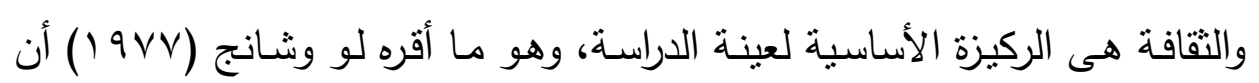

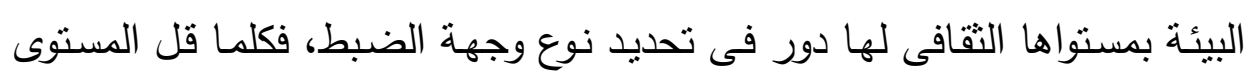
البيئى والتقافى كان اتجاه الضبط خارجى (Lao, Chuamge, 1977, p.1).

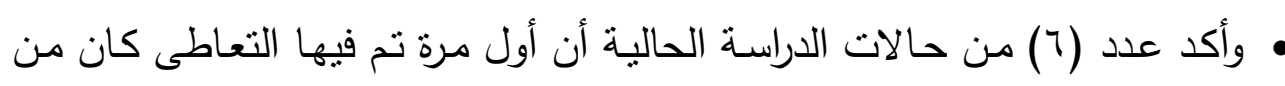

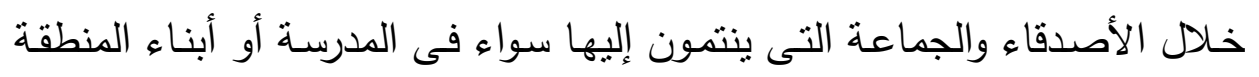


• فى حين أقر عدد (V) حالات من الدراسـة الحالية أنهم تعاطوا أدوية السعال

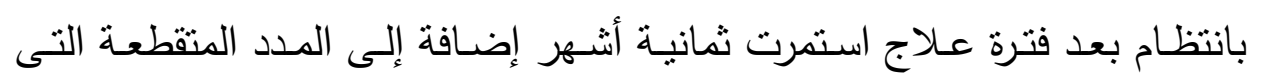

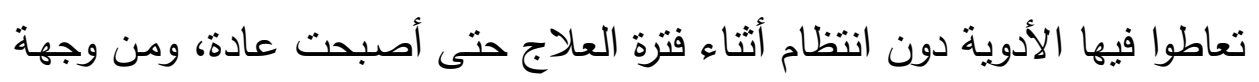
نظر عدد (r) حالات منهم أنها أفضل من التخخين.

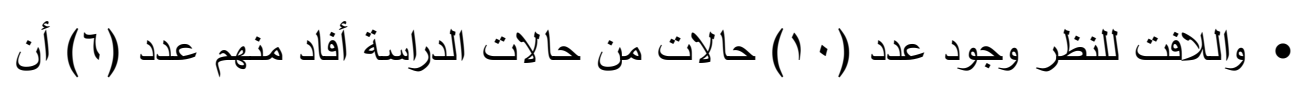

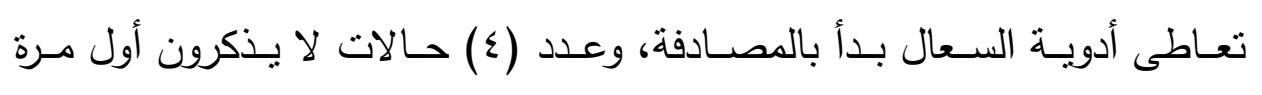
ل اللتعاطى بالمرة.

• كما اتضح أن جماعة الأقران لها دور فاعل فى توجيه وجهة الضبط وتصنيفها،

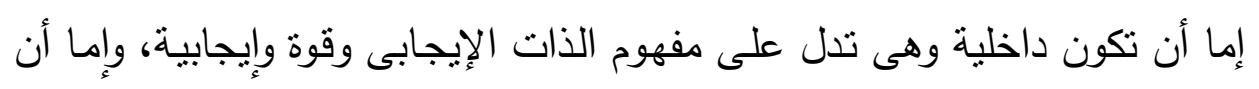

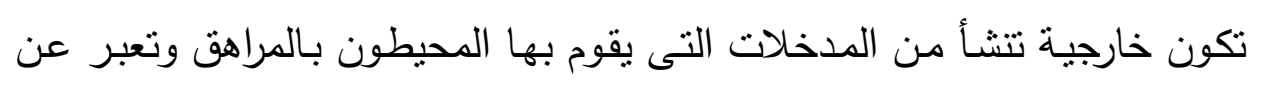
و وجود خلل فى وجهة الضبط. • وقد يعتبر المراهق أن تنخل الأسرة فى شأن التوقف عن التعاطى عدوان خارجى

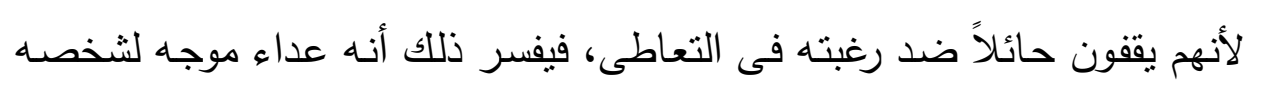

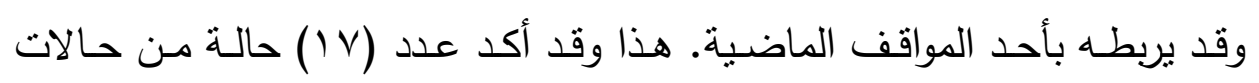

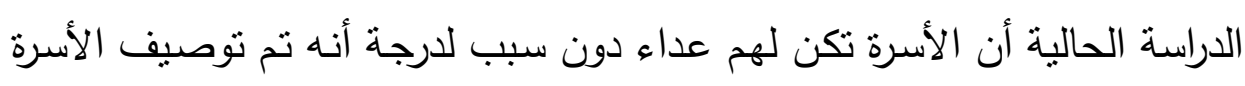

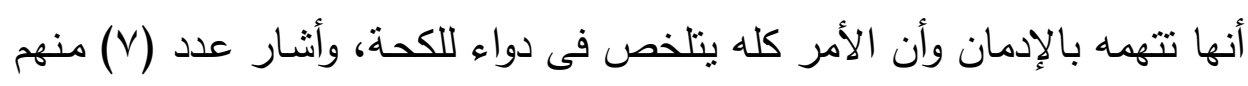

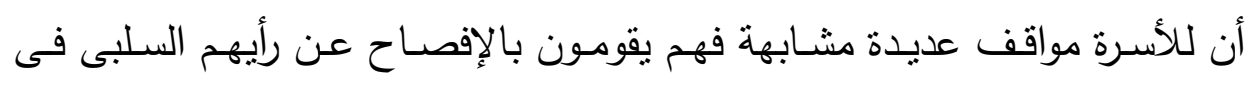

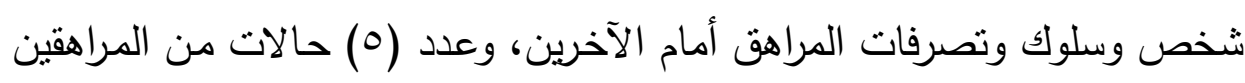

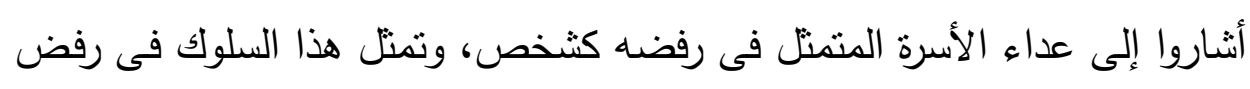

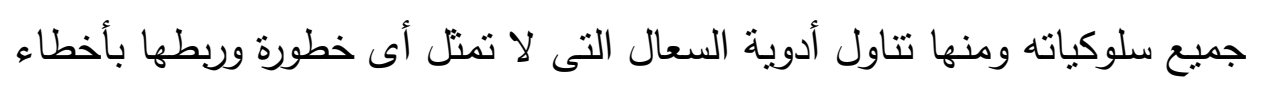

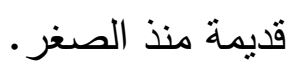


• ويوجد (0) حالات من المراهقين من بين حالات الدراسة الحالية أنشاروا أن عداء

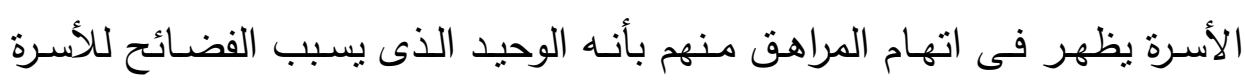

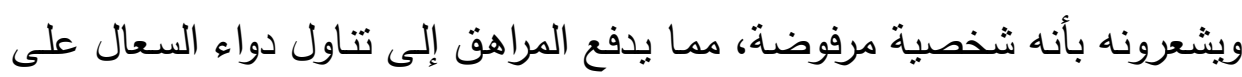
سبيل العناد، وأن هناك مقولة مسلمة يتداولونها (أنا كده كده مكروه).

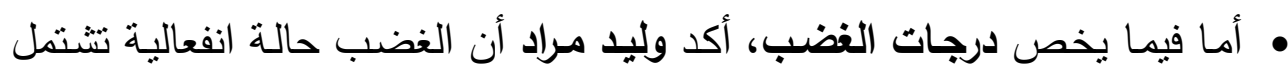

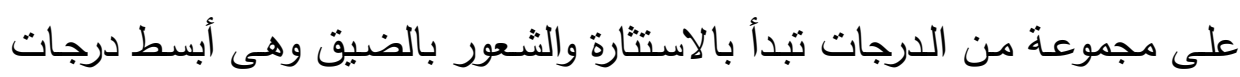

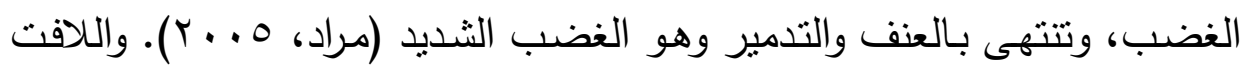

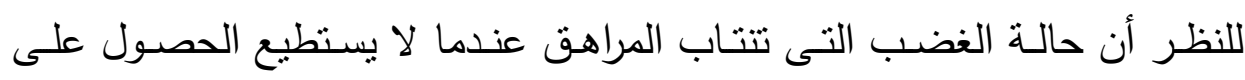

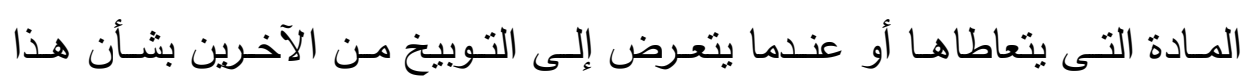

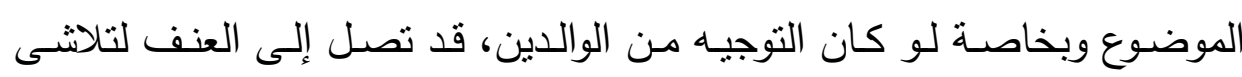

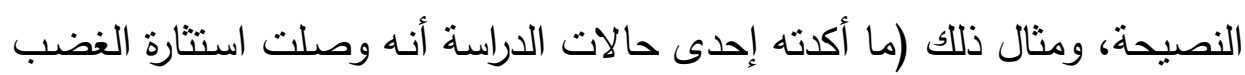
لديه إلى ضرب أمه حتى تتوقف عن النصح والإرشاد).

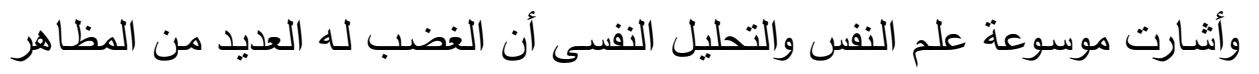

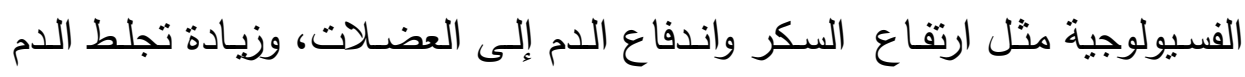

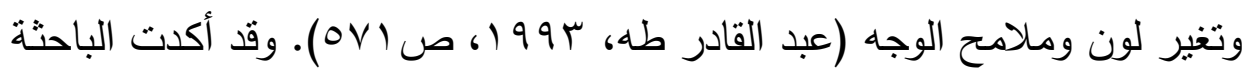

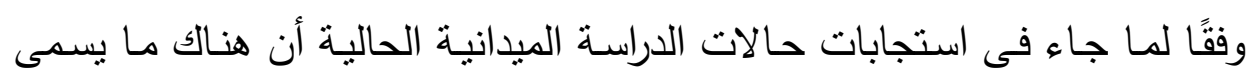
بالغضب الممنهج لاى المراهقين المتعاطين الذين يختزنون جميع الخبرات وردود

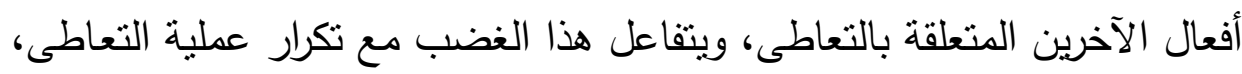
بل أحيانا يحاول المتعاطى الاستجابة للآخرين بالتوقف عن تتاول الأدوية المخدرة

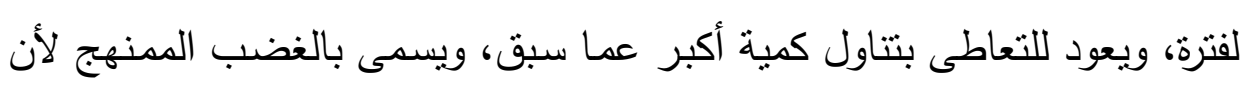

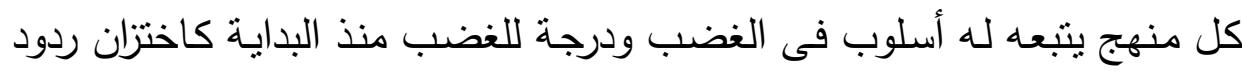

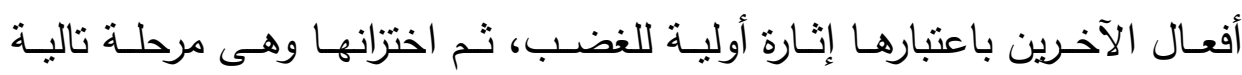


بتوصيف آخر لنوع غضب آخر ، ثم تتظيم الانفعال والغضب فى صورة مخرجات سلوكية غاضبة غير محسوبة ولكنها مقصودة.

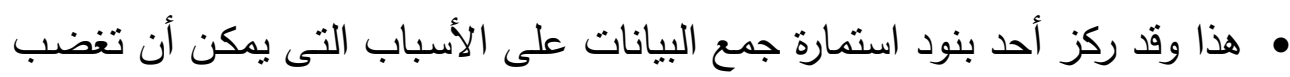

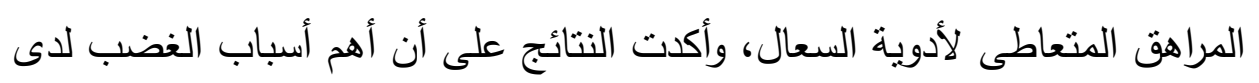

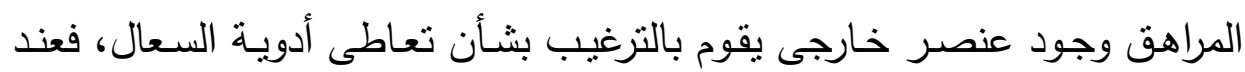

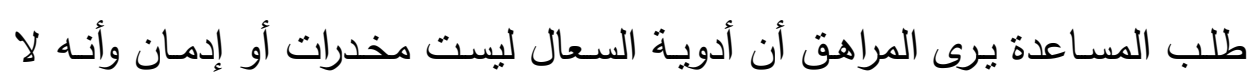

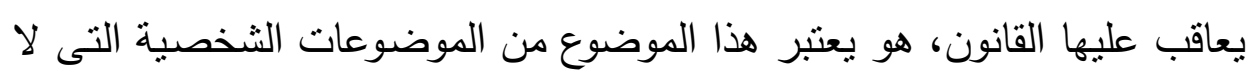
تعنى أحدًا سواه. • كما قد جاء على لسـان حالات الدراسـة الحاليـة من المراهقين المتعاطين أدويـة

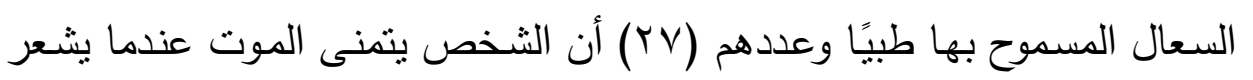

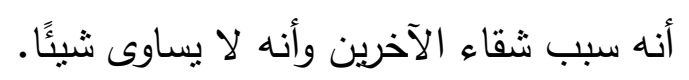

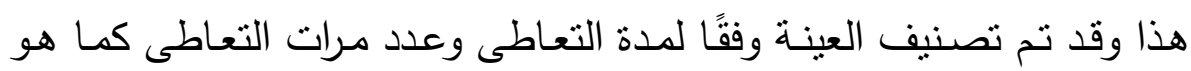
مبين بالجدولين (1، ؟) وقد استبعدت الباحثة من عينة الدراسة المراهقين المتعاطين من ذوى الإعاقة أو التشوهات الخلقية حتى لا تكون عاملاً مؤثرًا فى نتائج الدراسة.

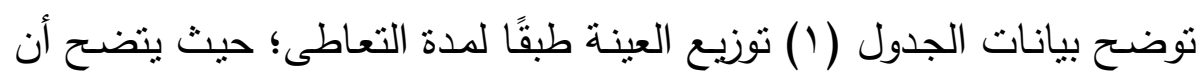

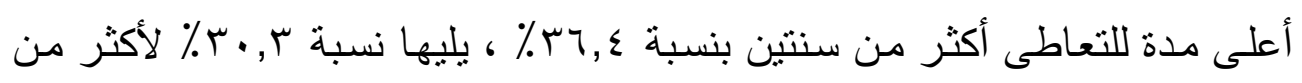

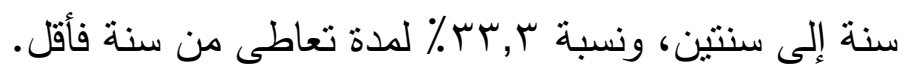


جدول (1)

\begin{tabular}{|c|c|c|}
\hline \multicolumn{3}{|r|}{ توزيع عينة } \\
\hline$\%$ & ك & مدة التعاطى \\
\hline r & 11 & من سنة فأقلّ \\
\hline$r \cdot r$ & 1. & أكثر من سنة إلى سنتين \\
\hline 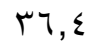 & Ir & أكثر من سنتين \\
\hline $1 \ldots$ & $r r$ & الإجمالى \\
\hline
\end{tabular}

كمـا توضـح بيانـات الجدول (Y) أن عينــة الدراسـة توزعت طبقًا لعدد مـرات

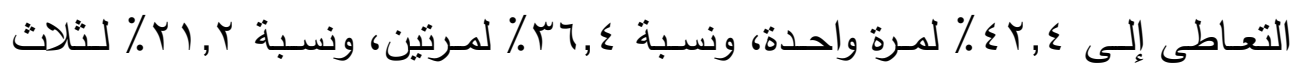
مرات.

جدول (ז)

\begin{tabular}{|c|c|c|}
\hline$\%$ & ك & عدد مرات التعاطي \\
\hline$\varepsilon r, \xi$ & $1 \varepsilon$ & مرة \\
\hline$r_{4, \varepsilon}$ & IT & مرتان \\
\hline$r, r$ & v & ثلاث مرات \\
\hline $1 \ldots$, & r & الإجمالى \\
\hline
\end{tabular}

\section{عرض النتائج وفقا للفروض}

1- - الفرض الأول

توجد علاقـة ارتباطيـة دالـة إحصـائيًا بـين درجـة الغضـب ووجهـة الضـبط الداخليـة

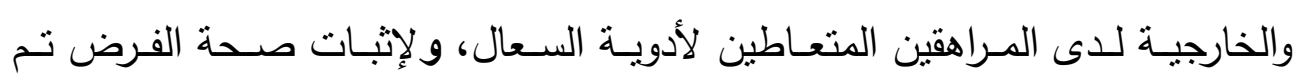

استخدام معامل ارتباط بيرسون Pearson Correlation Coefficient. 


\section{جدول (ז)}

قيمة معامل الارتباط بين وجهة الضبط ودرجة الغضب جأب

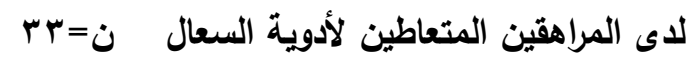

\begin{tabular}{|c|c|}
\hline مستوى الدلالة & قيمة معامل الارتباط \\
\hline$\cdot, \cdot 1$ & $\cdot, \wedge \leqslant \vee$ \\
\hline
\end{tabular}

يتضـح مـن بيانـات الجـدول (ب) وجـود علاقـة ارتباطيـة طرديـة ذات دلالـة

إحصـائية بـين درجـة الغضـب ووجهـة الضـبط الداخليـة والخارجيـة لـدى المـراهقين

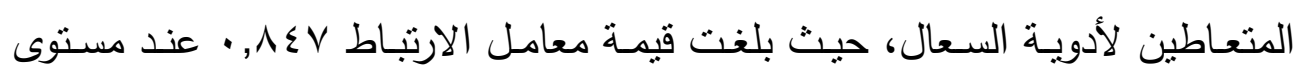

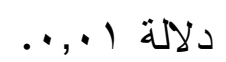

ويدل ذلك على أنسه كلمـا كانت درجـة وجهـة الضبط الخارجيـة مرتفعـة كانت

درجة الغضب شديدة، وكلما كانت وجهة الضبط الداخلية مرتفعة كانت درجة الغضب

ومن هنا ثبت صحة الفرض الأول أنه توجد علاقة ارتباطية بين وجهة الضبط

ودرجة الغضب.

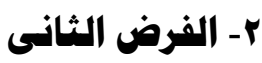

توجد علاقة ارتباطية دالة إحصائيًا بين درجة أشكال الغضب ووجهة الضبط الداخلية

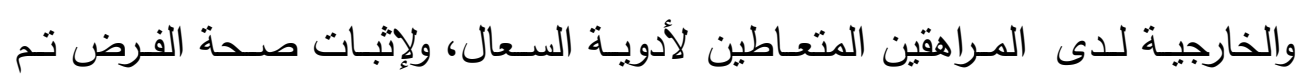
استخدام معامل ارتباط بيرسون Pearson Correlation Coefficient. 
جدول (؛ )

قيمة معامل الارتباط بين وجهة الضبط ودرجة أثكال الغضب

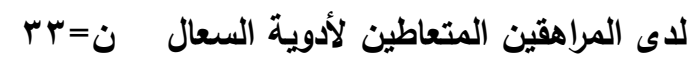

\begin{tabular}{|c|c|c|}
\hline \multicolumn{2}{|c|}{ وجهة الضبط } & وجهة الضبط \\
\hline مستوى الدلالة & قيمة معامل الارتباط & أثثكال الغضب \\
\hline$\cdot, .1$ & $\cdot, \lambda \vee V$ & سهولة الاستثارة للغضب \\
\hline$\cdot, \cdot 1$ & $\cdot$, ANV & حدة وتكرار الغضب \\
\hline$\cdot, \cdot$, & $\cdot, \lambda \cdot r$ & الأعراض النفسية والجسمية \\
\hline$\cdot, ., 1$ & •, УА५ & الغضب الداخلى الذاتى \\
\hline$\cdot, ., 1$ & $\cdot, \vee \vee \vee$ & الغضب الخارجى والسلوك الملاحظ \\
\hline
\end{tabular}

يتضـح من بيانات الجدول (ع) وجود علاقة ذات دلالمة إحصائية بين درجة

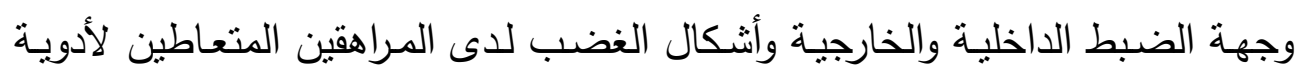

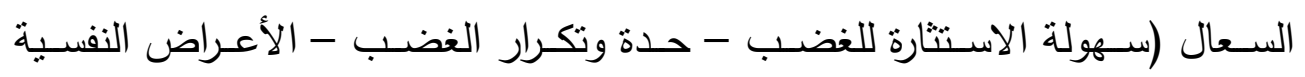

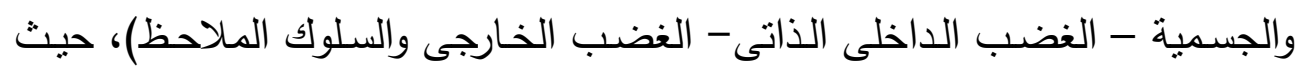

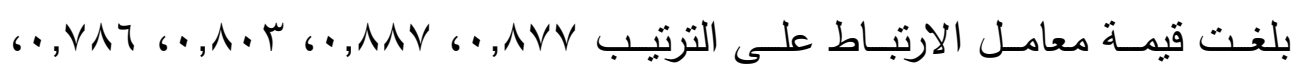

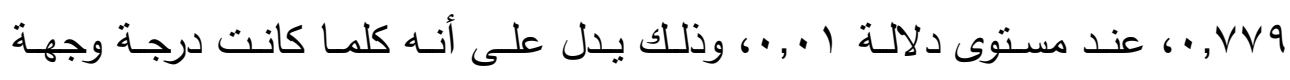

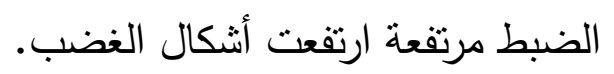

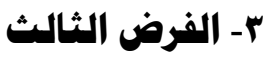

توجد علاقة ارتباطية دالة إحصائًًا بين درجة الغضب ومدة التعاطى لدى المراهقين

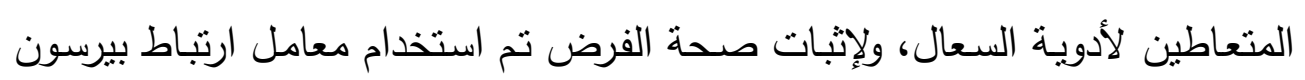
.Pearson Correlation Coefficient 


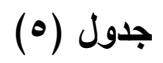

قيمة معامل الارتباط بين درجة أثكال الغضب ومدة التعاطى

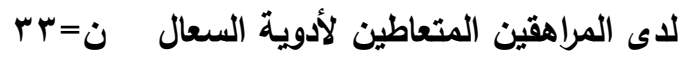

\begin{tabular}{|c|c|c|}
\hline \multicolumn{2}{|c|}{ مدة التعاطى } & مدة التعاطى \\
\hline مستوى الدلالة & قيمة معامل الارتباط & أشكال الغضب \\
\hline$\cdot, \cdot 1$ & , VTO & سهولة الاستثارة للغضب \\
\hline$\cdot, \cdot, 1$ &., $79 \mathrm{~V}$ & حدة وتكرار الغضب \\
\hline$\cdot, \cdot$, & . TVY & الأعراض النفسية والجسمية \\
\hline$\cdot, \cdot, 1$ & $\cdot, T \leqslant V$ & الغضب الداخلى الذاتى \\
\hline$\cdot, \cdot 1$ & $\cdot, 799$ & الغضب الخارجى والسلوك الملاحظ \\
\hline., .1 &.,$\vee 19$ & الدرجة الكلبة \\
\hline
\end{tabular}

يتضـح من بيانات الجدول (0) وجود علاقة ذات دلالمة إحصائية بين درجة

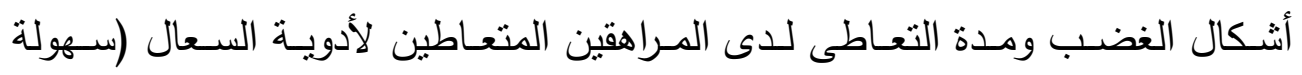

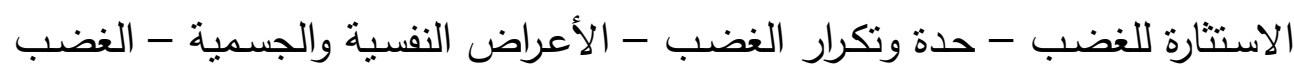

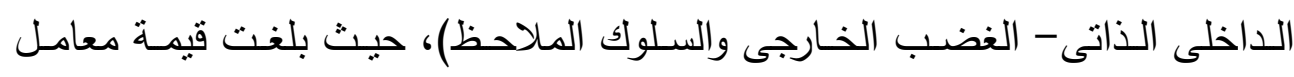

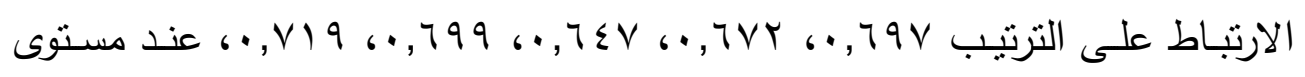

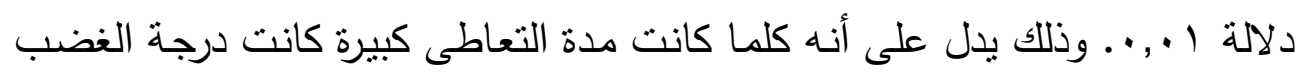

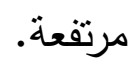

\section{ـ- الفرض الرابع}

توجد علاقة ارتباطية دالة إحصائًًا بين وجهة الضبط و ومدة التعاطى لدى المراهقين المتعاطين لأدوية السعال، ولإثبات صحة الفرض تم استخدام معامل ارتباط بيرسون

.Pearson Correlation Coefficient 
جدول (7) جبن (7)

قيمة معامل الارتباط بين وجهة الضبط ومدة التعاطى

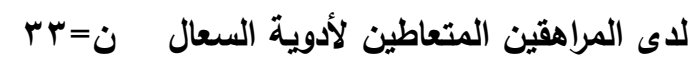

\begin{tabular}{|c|c|}
\hline مستوى اللالالة & قيمة معامل الارتباط \\
\hline$\cdot, \cdot$, & $\cdot, \vee \backslash \wedge$ \\
\hline
\end{tabular}

يتضـح من بيانات الجدول (†) وجود علاقة ذات دلالمة إحصائية بين درجة

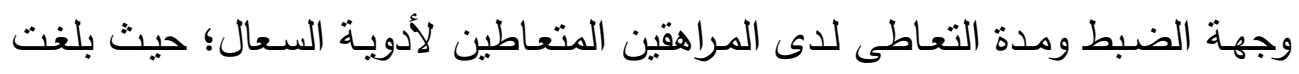

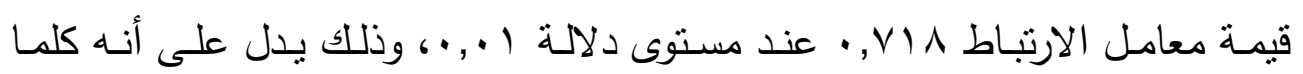
كانت مدة التعاطى كبيرة كانت درجة وجهة الضبط مرتفعة.

\section{ه- الفرض الخاهس}

توجد علاقة ارتباطية دالة إحصـائيًا بين درجة الغضب وعدد مـرات التعاطى لدى النى

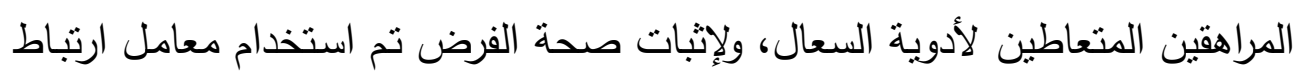

•بيرسون Pearson Correlation Coefficient

يتضح من بيانات الجدول التالى (V) وجود علاقة ذات دلالة إحصائية بين درجة أشكال الغضب وعدد مرات التعاطى لدى المراهقين المتعاطين لأدوية السعال النيال

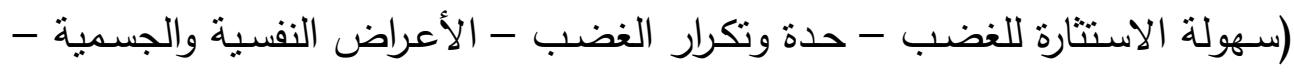

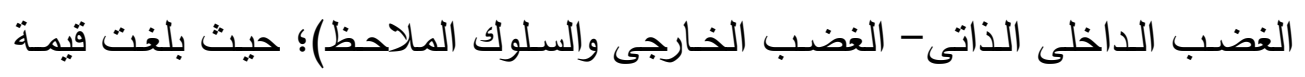

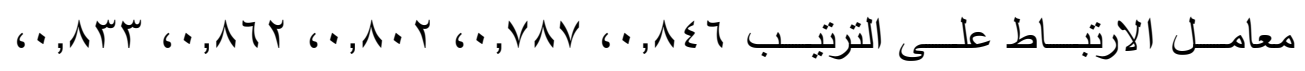

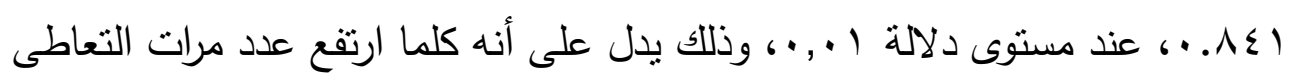
ارتفعت درجة الغضب. 


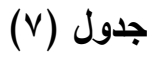

قيمة معامل الارتباط بين درجة أثكال الغضب ومدة التعاطى

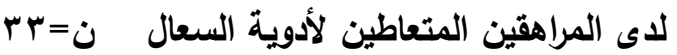

\begin{tabular}{|c|c|c|}
\hline \multicolumn{2}{|c|}{ مدة التعاطى } & \multirow[t]{2}{*}{ مدة التعاطى } \\
\hline مستوى الدالة & قيمة معامل الارتباط & \\
\hline$\cdot, \cdot 1$ & $\cdot, \wedge \leqslant 7$ & سهولة الاستثارة للغضب \\
\hline$\cdot, \cdot 1$ & $\cdot$, VA V & حدة وتكرار الغضب \\
\hline$\cdot, \cdot 1$ & $\cdot, \Lambda \cdot r$ & الأعراض النفسية والجسمية \\
\hline$\cdot, \cdot 1$ & 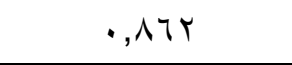 & الغضب الداخلى الذانى \\
\hline$\cdot, \cdot 1$ & ( & الغضب الخارجى والسلوك الملاحظ \\
\hline$\cdot, \cdot 1$ & $\cdot, \wedge \leqslant 1$ & الدرجة الكلية \\
\hline
\end{tabular}

1- الفرض السادس

توجد علاقـة ارتباطية دالـة إحصـائيًا بين وجهـة الضبط وعدد مرات التعاطى لدى المراهقين المتعاطين لأدوية السعال، ولإثبات صحة الفرض تم استخدام دعامل ارتباط بيرسون Pearson Correlation Coefficient.

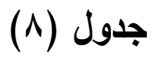

قيمة معامل الارتباط بين وجهة الضبط ومدة التعاطى

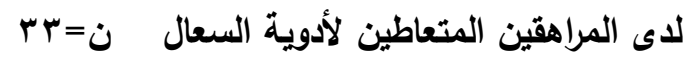

\begin{tabular}{|c|c|}
\hline مستوى الدلالة & قيمة معامل الارتباط \\
\hline$\cdot, \cdot$, & $\cdot, \wedge \leqslant \wedge$ \\
\hline
\end{tabular}

يتضح من بيانات الجدول السابق وجود علاقة ذات دلالة إحصائية بين درجة

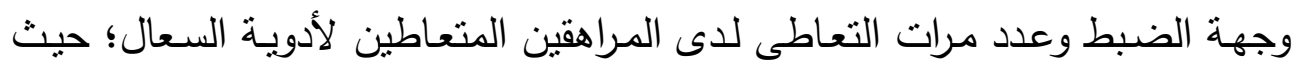




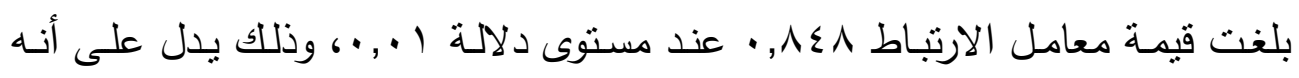
كلما زادت عدد مرات التعاطى ارتفعت درجة وجهة الضبط.

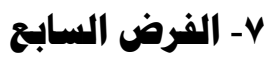

توجد فروق دالة إحصائيًا فى وجهة الضبط لدى المراهقين المتعاطين لأدوية السعال

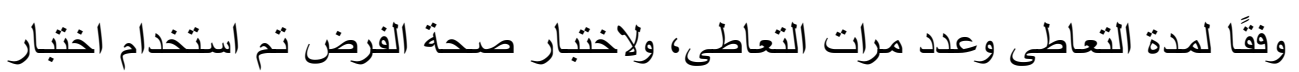
تحليل التباين الأحادى ANOVA.

جدول (9)

دلالة الفروق فى وجهة الضبط

لاى المراهقين المتعاطين لأدوية السعال وفقًا لمدة التعاطى

\begin{tabular}{|c|c|c|c|c|c|}
\hline مستوى & قيمة ف & الالنعراف & المتوسط & العدد & مدة التعاطى \\
\hline \multirow{3}{*}{$\cdot, \cdot 1$} & \multirow{3}{*}{$9,7 \wedge$} & $1 r, 0$ & $0 ., .9$ & 11 & من سنة فأقل \\
\hline & & $r, i r$ & $71,9$. & 1. & أكثر من سنة إلى سنتين \\
\hline & & $r, o v$ & $T \varepsilon, \varepsilon T$ & ir & أكثر من سنتين \\
\hline
\end{tabular}

يتضح من بيانات الجدول رقم (9) وجود فروق دالة إحصائيًا فى وجهة الضبط

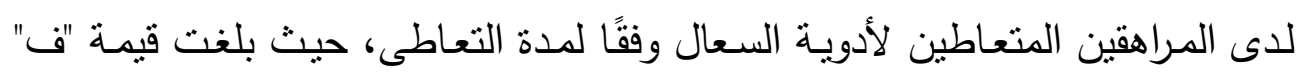

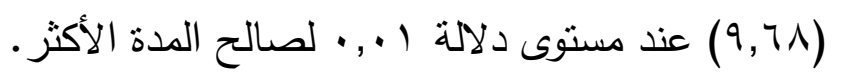




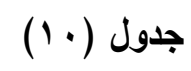

دلالة الفروق فى وجهة الضبط

لاى المراهقين المتعاطين لأدوية السعال وفقًا لعدد مرات التعاطى

\begin{tabular}{|c|c|c|c|c|c|}
\hline مستلوى & قيمة ف & المعيارى & المتوسط & العدد & عدد مرات التعاطى \\
\hline \multirow{3}{*}{$\cdot, \cdot 1$} & \multirow{3}{*}{$1 \cdot, \leqslant 9$} & $11,9 \varepsilon$ & $01, \varepsilon r$ & $1 \varepsilon$ & مرة \\
\hline & & $r, \wedge \varepsilon$ & $7 \pi, 0$. & IT & مرتان \\
\hline & & $1, \wedge 7$ & $70, \lambda 4$ & v & ثلاث مرات \\
\hline
\end{tabular}

يتضـح من بيانات الجدول السابق وجود فرق دال إحصائيًا في وجهة الضبط

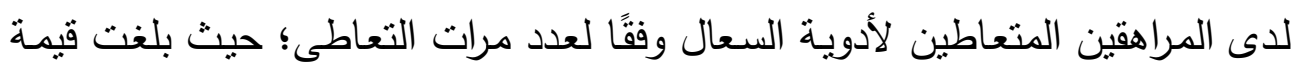

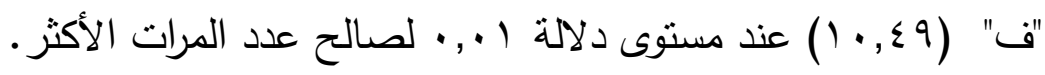

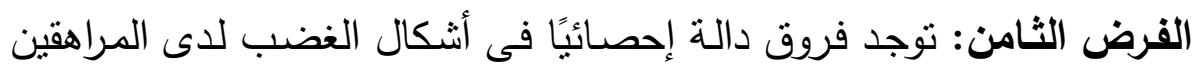

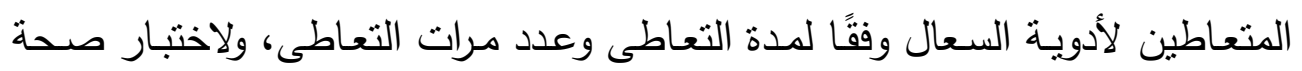
الفرض تم استخدام اختبار تحليل التباين الأحادى ANOVA. 
جدول (11)

دلالة الفروق فى درجة الغضب

لاى المراهقين المتعاطين لأدوية السعال وفقًً لددة التعاطى دلى

\begin{tabular}{|c|c|c|c|c|c|c|}
\hline مستوى & قيمة ف & الانحراف & المتوسط & العدد & مجموعة المقارنة & درجات الغضب \\
\hline \multirow{3}{*}{$\cdot, \cdot 1$} & \multirow{3}{*}{$r 1, r \leq$} & $1,1 \mathrm{r}$ & אוד,זו & 11 & من سنة فأقل & \multirow{3}{*}{ سهولة الاستثارة } \\
\hline & & $\cdot$, or & $1 \varepsilon, 0$ & $1 \cdot$ & أكثر من سنة إلى سنتين & \\
\hline & & $\cdot, 99$ & $10, \cdot 1$ & ir & أكثر من سنتين & \\
\hline \multirow{3}{*}{$\cdot, \cdot 1$} & \multirow{3}{*}{17,00} & $\cdot, 9 \leq$ & $1 r, 9$ & 11 & من سنة فأقل & \multirow{3}{*}{ حدة وتكرار الغضب } \\
\hline & & $\cdot, \Sigma Y$ & $1 \varepsilon, r$. & 1. & أكثر من سنة إلى سنتين & \\
\hline & &., 01 & $\mid \varepsilon, \varepsilon 1$ & ir & أكثر من سنتين & \\
\hline \multirow{3}{*}{$\cdot, \cdot 1$} & \multirow{3}{*}{17,99} & $1, \cdot r$ & $1,0 \leq$ & 11 & من سنة فأقل & \multirow{3}{*}{ الأعراض النفسية } \\
\hline & & $\cdot, \mathrm{V}$ & $1 \%, 9$. & 1. & أكثر من سنة إلى سنتين & \\
\hline & & 1,10 & $1 \varepsilon, 77$ & ir & أكثر من سنتين & \\
\hline \multirow{3}{*}{$\cdot, \cdot 1$} & \multirow{3}{*}{$10, Y 1$} & (1, & $9,9$. & 11 & من سنة فأقل & \multirow{3}{*}{ الغضب الداخلى الذاتى } \\
\hline & & $\cdot, 91$ & $11, \wedge$ & 1. & أكثر من سنة إلى سنتين & \\
\hline & & $1, \cdot r$ & $1 T, 17$ & ir & أكثر من سنتين & \\
\hline \multirow{3}{*}{$\cdot, \cdot 1$} & \multirow{3}{*}{$I V, V V$} & 1, (1, & $\wedge, 9$. & 11 & من سنة فأقل & \multirow{3}{*}{ والغضب الخارجى } \\
\hline & & $\cdot, \mathrm{VT}$ & $1 \cdot, 9$ & 1. & أكثر من سنة إلى سننين & \\
\hline & & l & 11,01 & ir & أكثر من سنتين & \\
\hline \multirow{3}{*}{$\cdot, \cdot 1$} & \multirow{3}{*}{$1 \wedge, 7 V$} & $0,1 \leq$ & $07,9$. & 11 & من سنة فأقل & \multirow{3}{*}{ الدرجة الكلية } \\
\hline & & $r, q$ & $70, r$. & 1. & أكثر من سنة إلى سنتين & \\
\hline & & $\varepsilon, V T$ & $7 V, 91$ & ir & أكثر من سنتين & \\
\hline
\end{tabular}

ويتضح من بيانات الجدول السابق وجود فروق دالة إحصائيًا فى درجة أثنكال

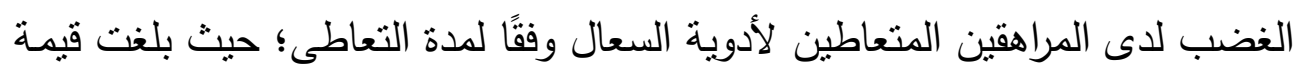
"ف" على التزتيـب ( مستوى دلالة ا +., • لصالح المدة الأكثر. 


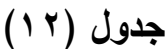

دلالة الفروق فى درجة الغضب

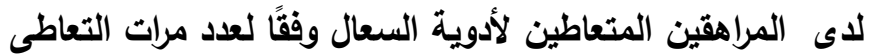

\begin{tabular}{|c|c|c|c|c|c|c|}
\hline الدالة & قيمة ف & المعيارى & المتوسط & 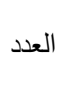 & عدد مرات التعاطى & درجات الغضب \\
\hline \multirow{3}{*}{$\cdot, \cdot 1$} & \multirow{3}{*}{ Tr,TV } & $\cdot, 9 \vee$ & Ir,VA & $1 \varepsilon$ & مرة مرة & \multirow{3}{*}{ سهولة الاستثارة للغضب } \\
\hline & & $\cdot, \times 1$ & $1 \leq, \wedge r$ & ir & 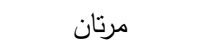 & \\
\hline & &., $0 \mathrm{r}$ & $10, \leqslant Y$ & v & ثلاث مرات & \\
\hline \multirow{3}{*}{$\cdot, \cdot 1$} & \multirow{3}{*}{$1 \wedge, 7$} & $\cdot$ •,AT & $M, \cdot v$ & $1 \varepsilon$ & 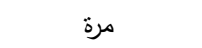 & \multirow{3}{*}{ حدة وتكرار الغضب } \\
\hline & & $\cdot, \leq 0$ & $1 \leq, Y_{0}$ & ir & 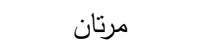 & \\
\hline & & $\cdot, \varepsilon \wedge$ & $|\leq, V|$ & $\checkmark$ & ثلاث مرات & \\
\hline \multirow{3}{*}{$\cdot, \cdot 1$} & \multirow{3}{*}{$r \wedge, \wedge)$} & $\cdot, 70$ & $1,0$. & $1 \varepsilon$ & 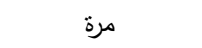 & \multirow{3}{*}{ الأعراض النفسية والجسمية } \\
\hline & & $1, \cdots$ & $1 \leq, 0$. & ir & مرنان & \\
\hline & & $\cdot, 79$ & $1 \leq, 10$ & v & ثلاث مرات & \\
\hline \multirow{3}{*}{$\cdot, \cdot 1$} & \multirow{3}{*}{$7, \cdot 1$} & דוד & $9, \wedge 0$ & $1 \leq$ & مرة مرة & \multirow{3}{*}{ الغضب الداخلى الذاتى } \\
\hline & & $\cdot, \times 1$ & $1 Y, 17$ & ir & مرتان & \\
\hline & & $\cdot, \leqslant \wedge$ & $|r, Y|$ & v & ثلاث مرات & \\
\hline \multirow{3}{*}{$\cdot, \cdot 1$} & \multirow{3}{*}{ ri,v. } & $\cdot, \mathrm{\vee} \wedge$ & $9, \cdots$ & $1 \varepsilon$ & 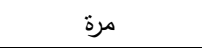 & \multirow{3}{*}{ الغضب الخارجى والسلوك } \\
\hline & & 1,17 & $11, \varepsilon 1$ & ir & مرنان & \\
\hline & & $\cdot, 79$ & 11,10 & v & ثلاث مرات & \\
\hline \multirow{3}{*}{$\cdot, \cdot 1$} & \multirow{3}{*}{$r_{q, \varepsilon 0}$} & r,Tr & $O V, Y$, & $1 \varepsilon$ & 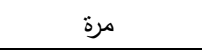 & \multirow{3}{*}{ الدرجة الكلية } \\
\hline & & r,マ^ & $7 V, 17$ & Ir & 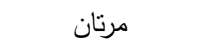 & \\
\hline & & r & $79,0 \mathrm{~V}$ & v & ثلاث مرات & \\
\hline
\end{tabular}

يتضح من بيانات الجدول (Y M) وجود فروق دالة إحصائًا فى درجة أشكال

الغضب للدى المـراهقين المتعـاطين لأدويـة السـعال وفقًا لعدد مـرات التعاطى؛ حيث

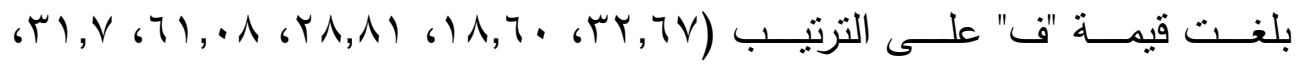

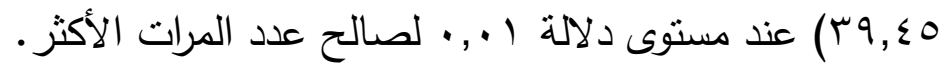




\section{مناقشة نتائج الدراسة}

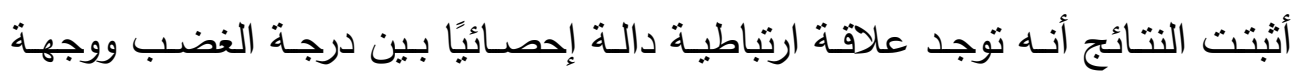

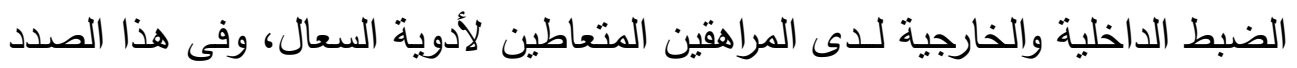

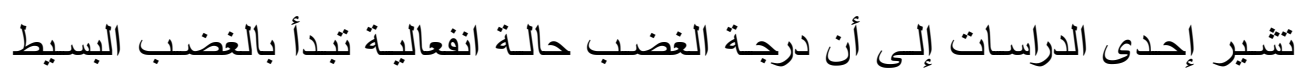

$$
\text { كالاستثارة (مراد، ه م. . ب، مرجع سابق). }
$$

وقد تكون هذه الاستثارة مرتبطة بعدم الحصول على هلى أدوية السعال أو التوبيخ

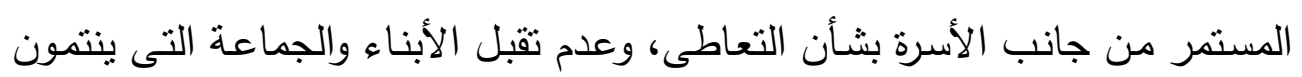

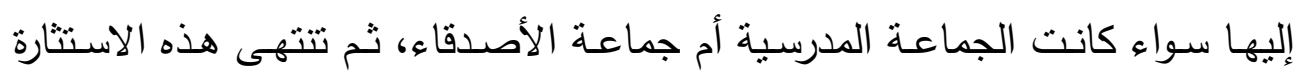

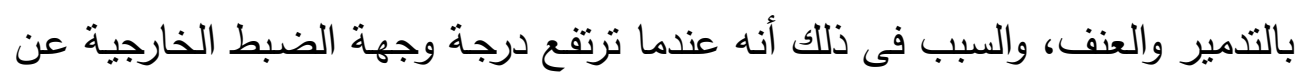

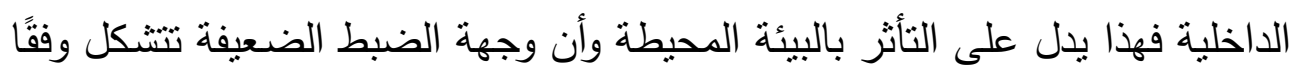
للمتغيرات المحيطة.

وهو ما أكدته نيفين زهلان فى دراسة أجرتها عن علاقة التعاطى بالمشكلات

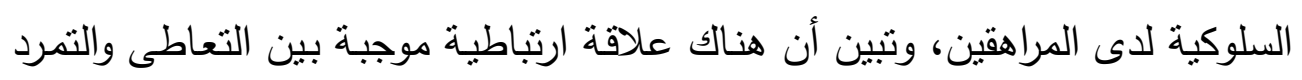

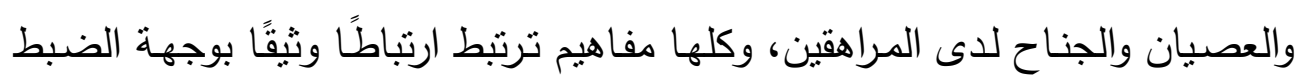

$$
\text { والغضب (محمد زهران، مرجع سابق). }
$$

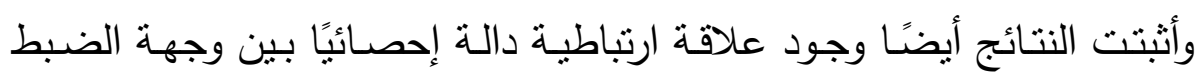

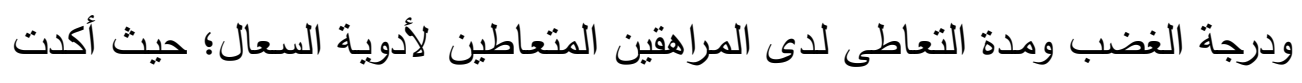

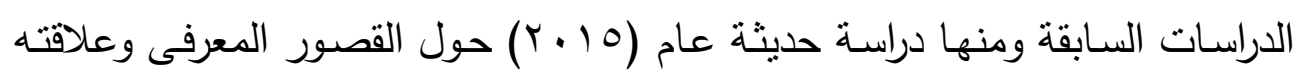

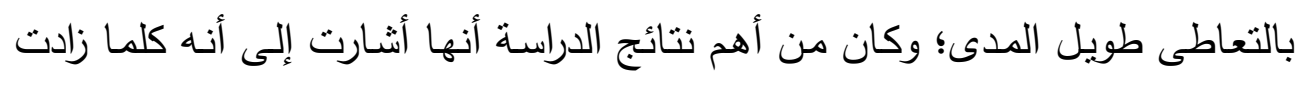

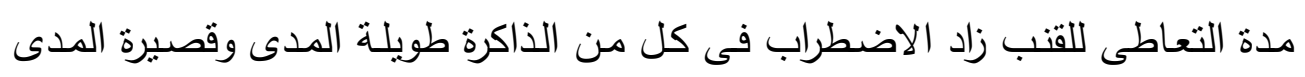
والانتباه (Mcculye, 2015). 
وهو ما أكدته المسلمات العلمية المتعلقة بوجهة الضبط أنها مرتبطة بمعامل الذكاء لتتكيل وجهة الضبط ما إذا كانت خارجية أو داخلية كأحد العوامل التى تتدخل فى تشكيل وجهة الضبط. أما فيما يخص درجة الغضب وعدد مرات التعاطى لدى المراهقين المتعاطين لأدوية السعال أثنارت النتائج إلى وجود علاقة ارتباطية دالة إحصائيًا؛ وفى هذا أكداني

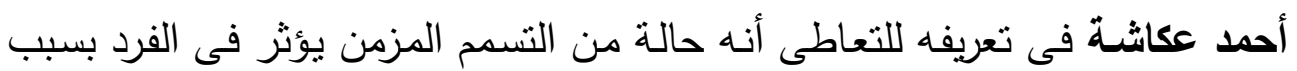

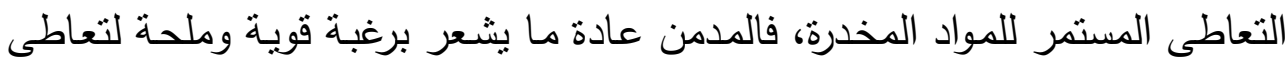
هذه المواد، ويحاول الحصول عليها بأى طريقة، ويتجه المدمن باستمرار إلى زيادة

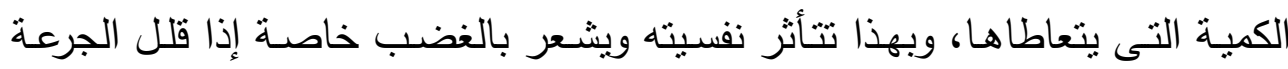

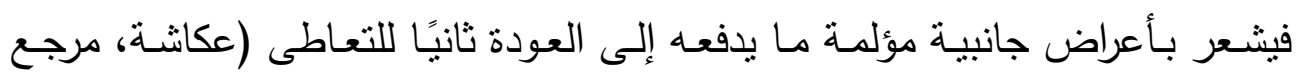

ويضيف مصطفى سـويف أن التعاطى المتكرر يكون نتيجة لانشخال المدمن

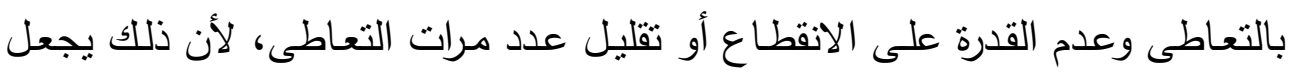

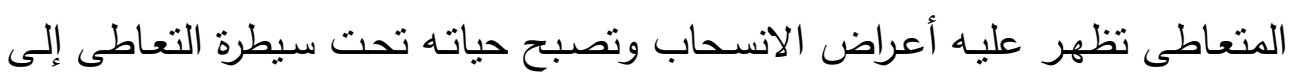
درجة تصل إلى استبعاد أى نشاط آخر (سويف، مرجع سابق).

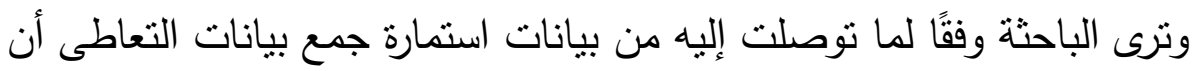

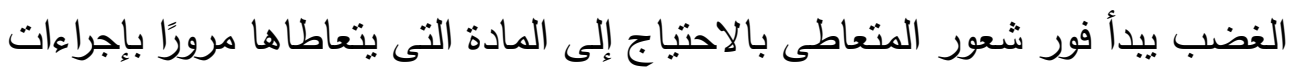

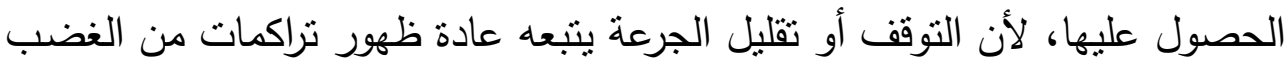
تتكون لايه وبخاصة من الأسرة والمحيطين به.

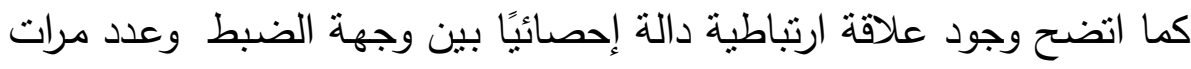

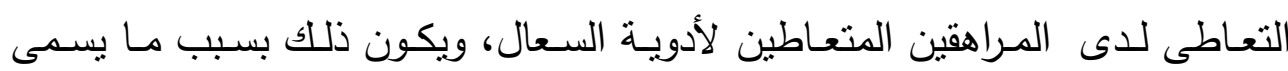

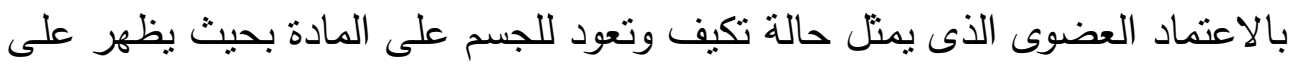


المتعاطى اضطرابات نفسية وعضوية عند امتتاعه عن تتاولها فجأة، وهناك العديد من مظاهر السلوك متعلقة بظاهرة الاعتماد النفسى على العقاقير والأدوية الدخدرة، وهو مما سبق الإثارة إليه (الدمرداش، مرجع سابق).

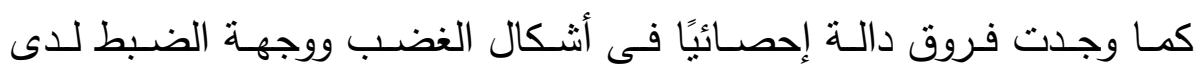
المراهقين المتعاطين لأدوية السعال وفقًا لمدة التعاطى وعدد مرات التعاطى، وقد أنثار عـادل صـادق عـام 1911 إلى تصنيف الطب النفسى للثخصية الإدمانية ومنها الثخص العقابى للذات، وتتكون هذه الثخصية نتيجة لأسلوب خاطئ فى التربية التى التى

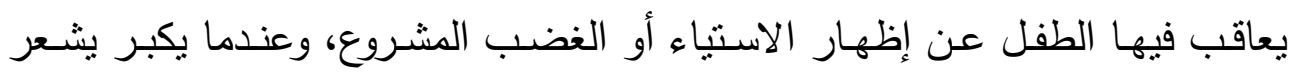
بالقلق الثديد عند إحساسه بالرغبة فى التعبير عن هذا الغضب فيلجأ التبأ لأية مادة مخدرة

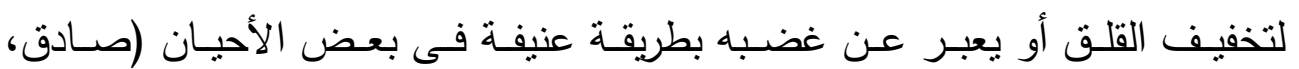

إضافة إلى أن كثيرًا من الدراسات العلمية أكدت وجود علاقة قوية بين وظيفة الهرمونات الجنسية والتفاعل العاطفى عند المراهقين، بمعنى أن المستويات الهرمونية

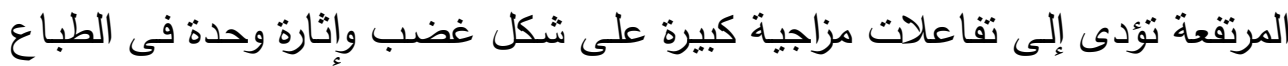
.(Vedvarma, op. cit)

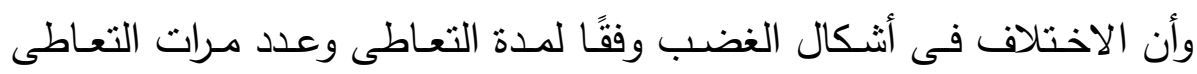
يمكن إرجاعها إلى ما يسمى بالاعتماد النفسى وقد يظهر ذلك بشدة؛ ويتحدد الغضب

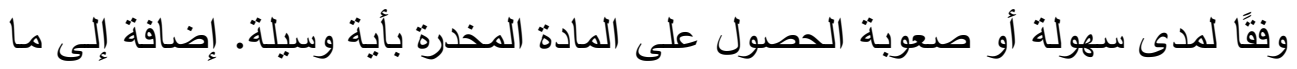
ذكره سويف بشأن الجرعة الزائدة والتى تفسر جزئية علاقة شكل ودرجة الغضب التباد بعدد

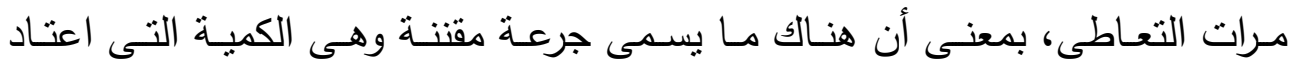
المتعاطى أن يتعاطاها، فإذا زادت الجرعة عن ذلك في في إحدى مرات التهات التعاطى فإنها تحدث آنارًا معاكسة حادة وتكون هذه الآثار عضوية أو نفسية (سويف، مرجع سابق). 
كما اتضـح من خلال النتائج وجود علاقة ارتباطية دالة إحصائيًا بين وجهة

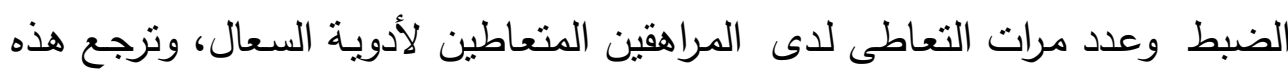

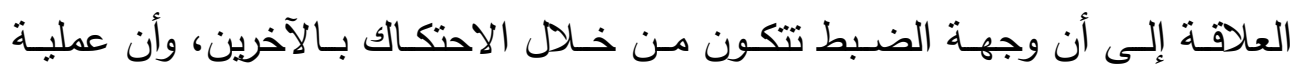

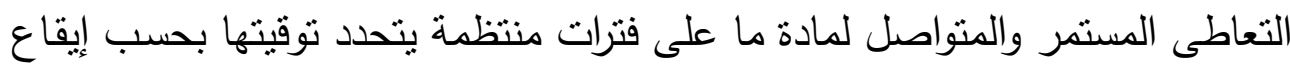
داخلى سيكوفسيولوجى، وهى حالة انتقال من الواقع المحبط الفاشل للذات إلى نظام

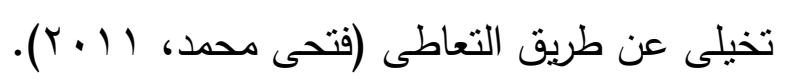

وهنا نجد أن الواقع الفاثل الذى يحيط المتعاطين لأدوية السعال (عينة الدراسة)

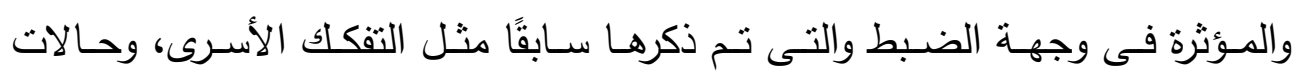

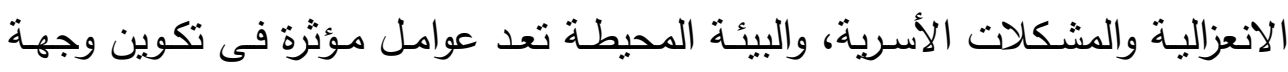

$$
\text { الضبط. }
$$

كما وجدت فروق دالة إحصائيًا فى وجهة الضبط لدى المراهقين المتعاطين

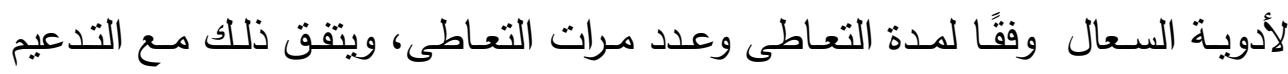

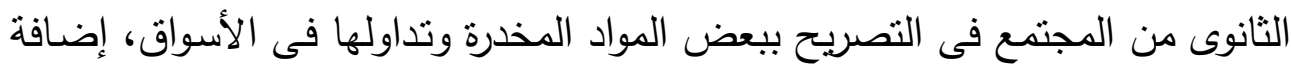

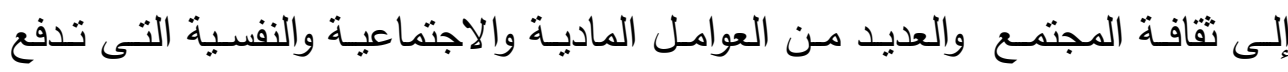

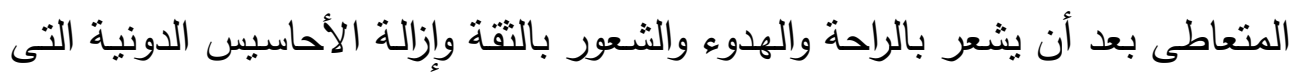

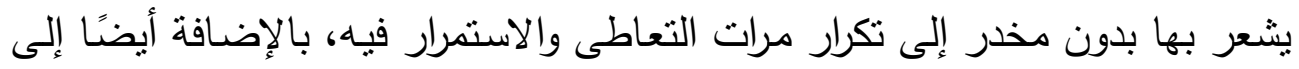

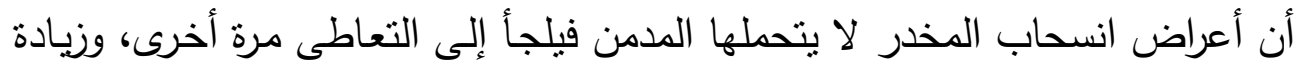
الجرعة عن المعدل المعتاد عليه، وهو ما أثنتته الدراسة الميدانية الحالية.

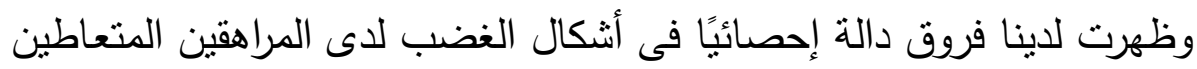

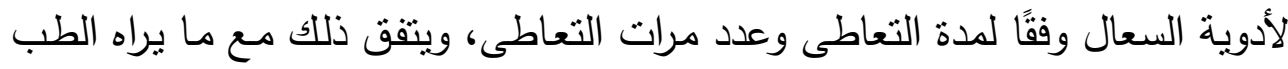

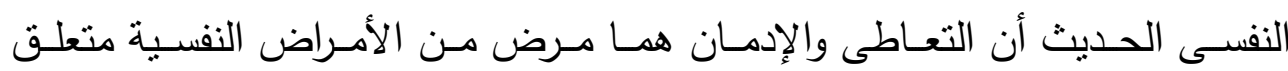

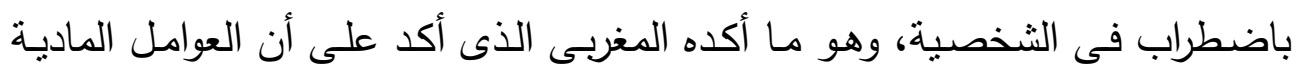


والاجتماعية والنفسية منل الأساليب التربوية الفاشلة، وانعدام السلوك الإيجابى وتتاقض

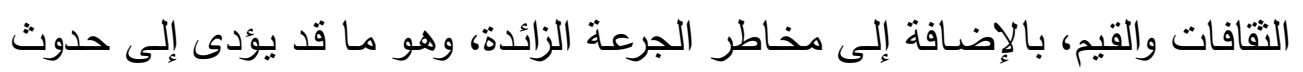
آثار معاكسة حادة على المستوى النفسى والعضوى (المغربى، مرجع سابق).

\section{التوصيـات}

• تصميم برامج تأهيليـة لإعـادة تشكيل وجهة الضبط بوجـه عـام للدى المتعـاطين ووجهة الضبط الخارجية بصفة خاصة لدى الفئة نفسها.

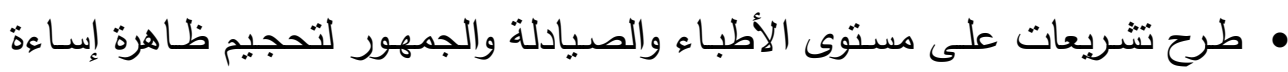
استخدام الأدوية المشروعة إلا بمحددات معينة.

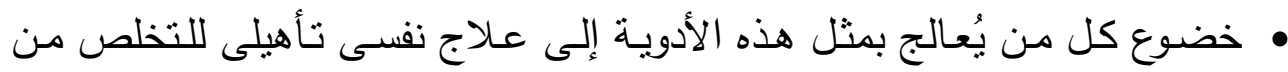
الاعتماد العضوى والنفسى على منل هذه الأدوية.

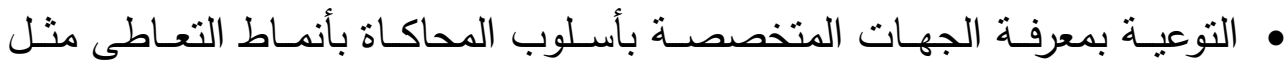

$$
\text { (التعاطى التجريبى - الاستكثافى...... إلخ). }
$$
• التوعية على مستوى المؤسسات التعليمية والثنبابية. 


\section{المراجـــ}

1- إسلام (أحمد). (1 . ب). التلوث الكيميائى وكيمياء التلوث. الطبعة الأولى. القاهرة، دار الفكر

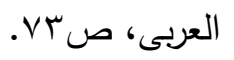

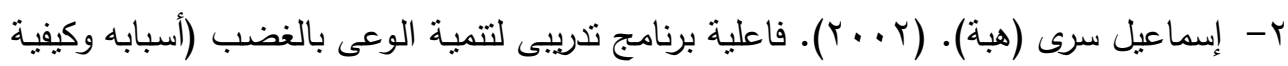

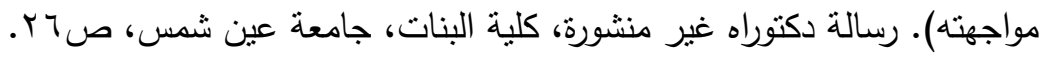

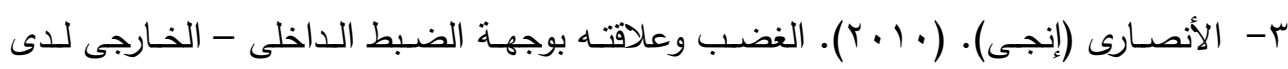

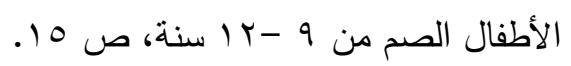

ع- الدمرداث (عادل). (ץ/911). الإدمان مظاهره وعلاجه. كتاب الحرية، عالم الدعرفة، القاهرة، rore

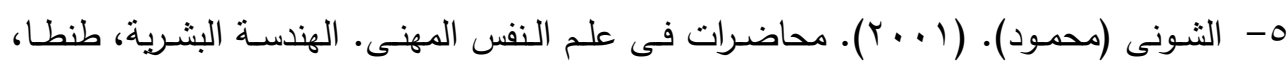

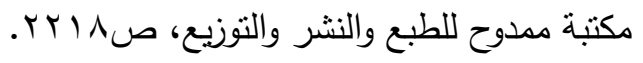

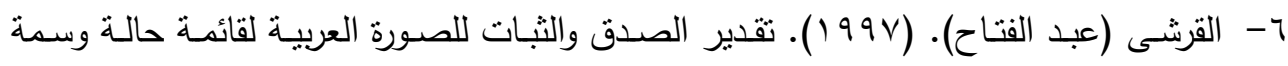

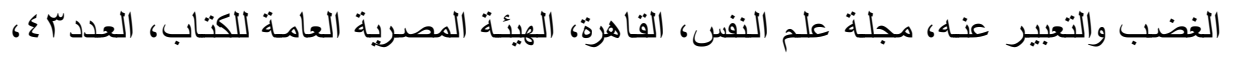

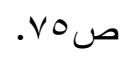

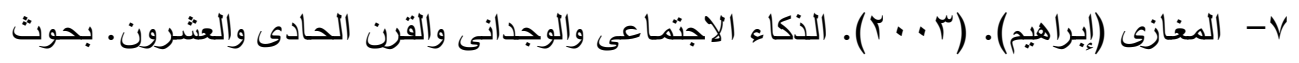

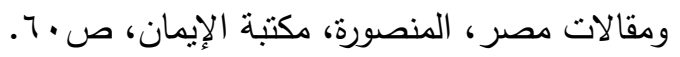

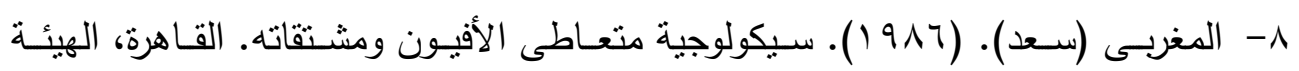

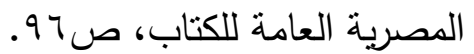

9- برونو (فرانك). (997) (19). الأعراض النفسية. ترجمة رزق سند، القاهرة، دار الحكيم لطباعة

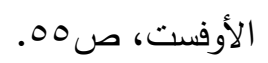

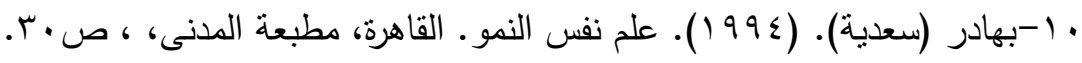

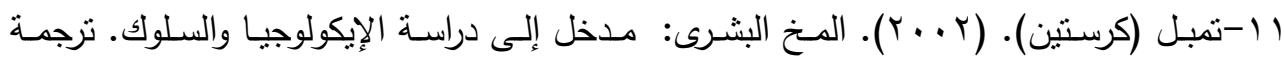

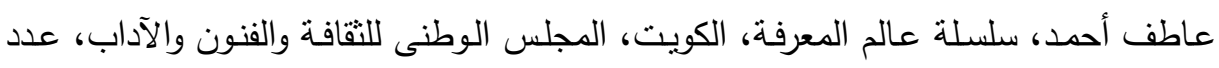

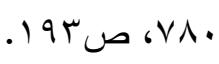




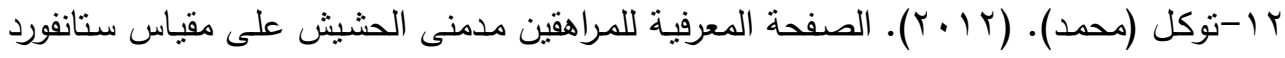

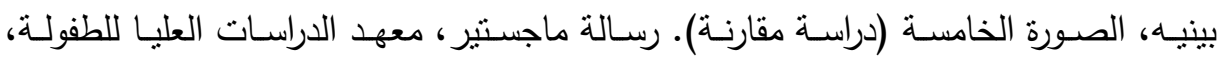

$$
\text { טגו }
$$

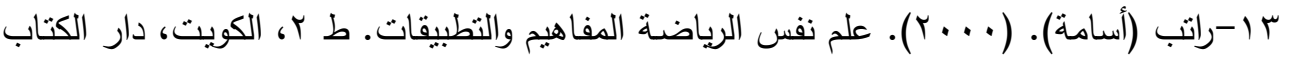

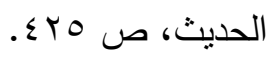

ـ ا-روبنس (بام)؛ و سكوت (جين). (... (ب). الذكاء الوجدانى. نرجمة: صفاء الأعسر وعلاء كفافى، القاهرة، دار قباء للنشر والتوزيع.

10-صادق (عادل). (71911). الإدمان له علاج. القاهرة، مؤسسة دار الأخبار للنشر والتوزيع. 7 ا-عبد الحميد منسى (محمود). (991 (1). المستوى الاقتصادى الاجتماعى فى البيئة السعودية. كلية التربية، جامعة الملك عبد العزيز ، المدينة المنورة.

V ا-عبد العزيز قلمبان (رذاذ). (ץ . . ץ). مستتفى الملك فيصل التخصصى، مركز أبحاث، جدة. 1 1-عبد العظيم رجيعة (محمد). (9 . . ץ). الآثار النفسبة لتعاطى وإدمان المخدرات. جامعة نايف للعلوم الأمنية. 9 ا-عبد القادر طـه (فرج). (199 (1). موسـوعة علم النفس والتحليل النفسى. الطبعـة الأولىى، ص n n

• ץ-عبـد القوى (سـامى). (1990). علـم الـفس الفسـيولوجى. مكتبـة النهضــة المصـرية، ط؟،

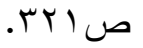

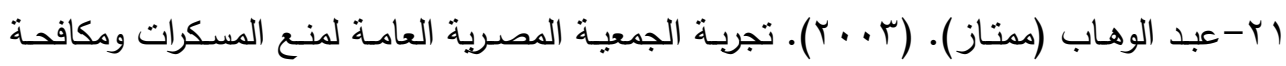

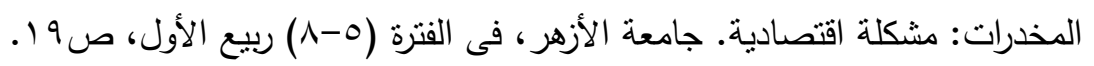

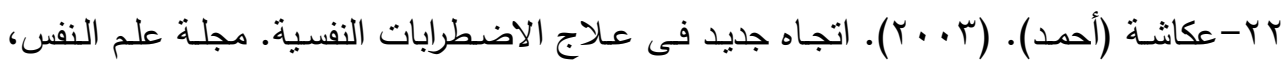

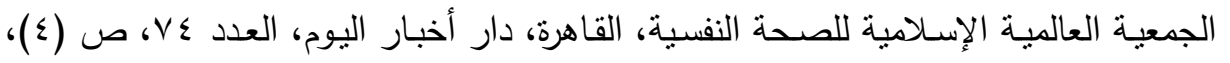

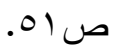
rץ-فتحى محمد (محمد). (1) • (Y). إدمان المخدرات والمسكرات بين الواقع والخيالى من منظور التحليل النفسى. مكتبة الأنجلو المصرية. 


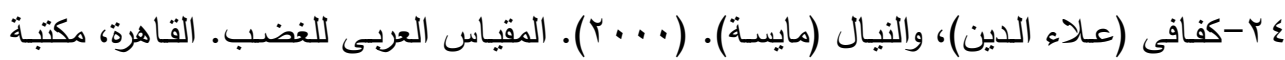

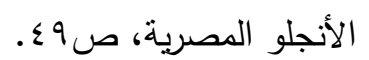

هץ-كفافى (عـلاء الدين)، والنيال (مايسـة). الغضب وعلاقته ببعض متغيرات الثخصية. دراسـة

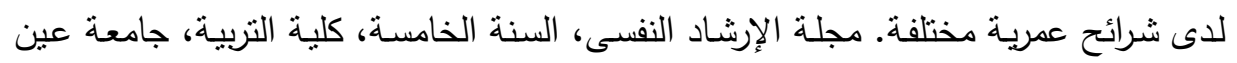

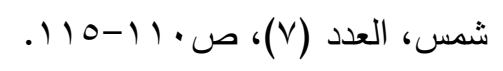

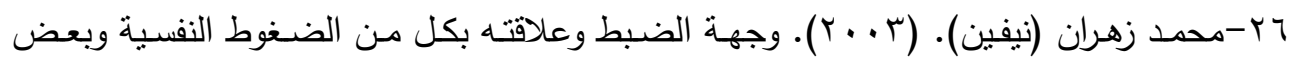

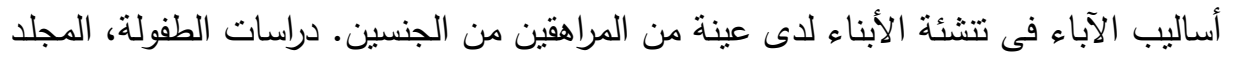

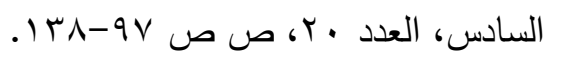

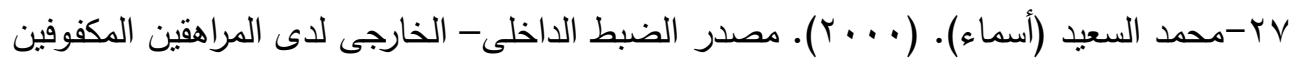

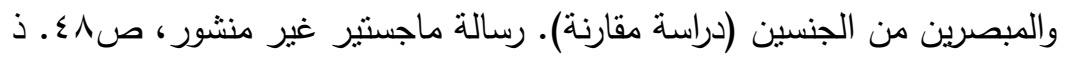

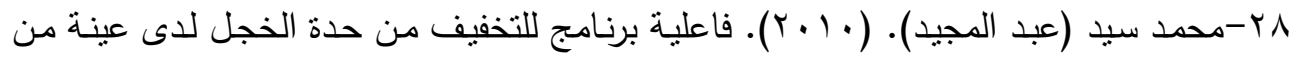

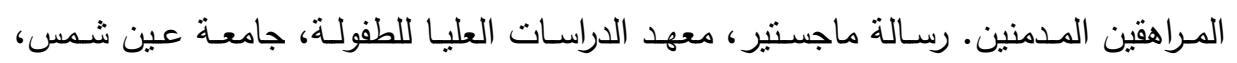

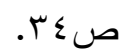

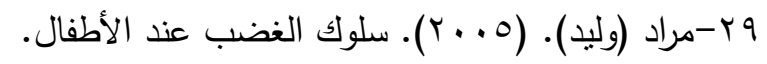

http:www.sehha.com.mentalhealth.baby06 2542005

• ץ-وجيـه محمود (إبراهيم). (19191). المراهقة وخصائصها ومشكلاتها. القاهرة، دار المعارف،

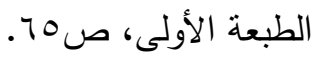

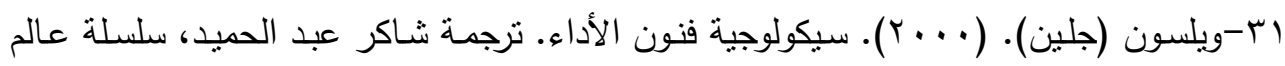

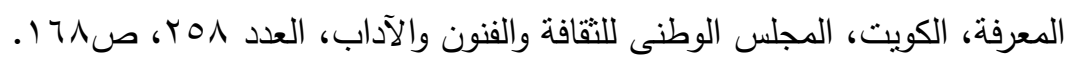

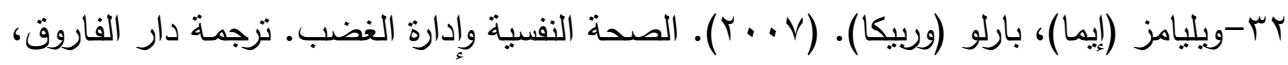

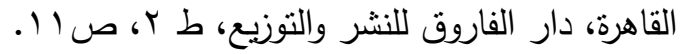

rT-يوسف عبد الرحمن الضبع (ثناء). (71911). العلاقة بين القلق وإدراك الفرد لمركز التحكم

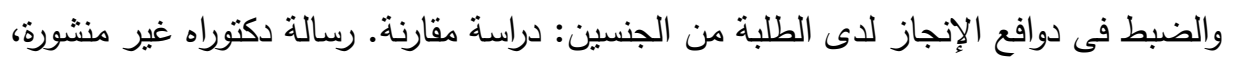

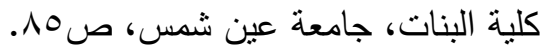


34- Benson B., \& Fushs C. (1999). Anger-arousing Situations and Coping Responses of Aggressive Adults with Intellectual Disability. Journal of Intellectual and Developmental Disability, Vol. 2-f (3), pp. 210-211.

35- Freedman S.A. (1991). Sex Gender and Locus of Control in College Students. Paper Presented at the Annual Convention of the American Psychological Association, 100th, Washington, DC, (1-1- 18), p. 32.

36- Gentry, Dolye. (2000). Anger Free: Ten Basic Steps to Managing Your Anger. Quill an Imprint of Harper Collins Publishers, p. 44.

37- Lao R., \& Chuange C. (1977). Locus of Control and Chance College Students. Journal of Cross-culture Psychology, Vol. B (3), p. I.

38- March H., \& Richards G. (1989). Multidimensional Self Concepts and Perceptions of Control, Construct Validation of Responses by Children. Journal Education Pychology, Vol. 81, p. 521.

39- McClure, Erin A. et al. (2015). Objective and Subjective Memory Ratings in Cannabis-Dependent Adolescents. The American Journal on Addictions / American Academy of Psychiatrists in Alcoholism and Addictions, Vol. 24 (1), pp. 47-52.

40- Sosis R.H. (1974). Internal- External Control and the Perception or Responsibility of Another for an Accident. Journal Person Social Psychology, Vol. 30, p. 390.

41- Spielberger C. D.; Jacobs G.; Russel S.\& Crane R.S. (1983). The State-trait Anger Scale. in J.N. Butcher and C.D. Spielberger (eds), Advances in Personality Assessment, Lawrence Erlbaum Associates, Inc., Vol. 11 (2), pp. (159-187).

42- Vedvarma, (1996). Violence in Children and Adolescent. London, p. 103. 


\section{Abstract \\ The Relationship Between Self Control and Anger \\ In Adolescents Abusing Cough Medicines}

\section{Ola Abdelfatah}

The current paper discusses the relationship between anger and self control in a sample of adolescents abusing cough medicines, as an attempt to reveal the role of each concept in the continuing of abuse. The sample consists of 50 adolescent males from Abassyia Hospital for Psychological and Neurological Diseases, aging between 14 and 18 years old.

A number of tools have been applied: data collection form prepared by the researcher; Anger scale prepared by Ing al Ansary; and self control scale prepared by Alaa el kafafy. The study concluded that there is a functinonal correlation relationship between anger degree and internal and external self control in adolescents abusing cough medicines; more over, there is a statistical function relationship between self control, anger degree, duration and times of abuse of cough medicines. There are also statistical function differences in the forms of anger in adolescents abusing cough medicines according to the duration and times of abuse. 